\title{
Crustal structure of the ultra-slow spreading Knipovich Ridge, North Atlantic, along a presumed ridge segment center
}

\author{
Aleksandre Kandilarov $\cdot$ Hildegunn Landa $\cdot$ \\ Rolf Mjelde • Rolf B. Pedersen • Kyoko Okino • \\ Yoshio Murai
}

Received: 5 March 2009/ Accepted: 26 July 2010/Published online: 24 August 2010

(c) The Author(s) 2010. This article is published with open access at Springerlink.com

\begin{abstract}
A combined ocean bottom seismometer, multichannel seismic reflection and gravity study has been carried out along the spreading direction of the Knipovich Ridge over a topographic high that defines a segment center. The youngest parts of the crust in the immediate vicinity of the ridge reveal fractured Oceanic Layer 2 and thermally expanded and possibly serpentinized Oceanic Layer 3. The mature part of the crust has normal thickness and seismic velocities with no significant crustal thickness and seismic velocity variations. Mature Oceanic Layer 2 is in addition broken into several rotated fault blocks. Comparison with a profile acquired $\sim 40 \mathrm{~km}$ north of the segment center reveals significant differences. Along this profile, reported earlier, periods of slower spreading led to generation of thin crust with a high $\mathrm{P}$-wave velocity $(V \mathrm{p})$, composed of a mixture of gabbro and serpentinized mantle, while periods of faster spreading led to generation of more normal gabbroic crust. For the profile across the segment center no clear relation exists between spreading rate and crustal thickness and seismic velocity. In this study we have found that higher magmatism may lead to generation of oceanic crust with normal thickness even at ultra-slow spreading rates.
\end{abstract}

\footnotetext{
A. Kandilarov $(\bowtie) \cdot$ H. Landa $\cdot$ R. Mjelde $\cdot$ R. B. Pedersen Department of Earth Science, University of Bergen, Allegaten 41A, 5007 Bergen, Norway

e-mail: Aleksandre.Kandilarov@geo.uib.no

K. Okino

Ocean Research Institute, University of Tokyo, Tokyo, Japan

Y. Murai

Institute of Seismology and Volcanology, Hokkaido University,

Sapporo, Japan
}

Keywords Knipovich Ridge · Ultra-slow spreading · Crustal structure $\cdot$ Refraction seismics $\cdot$ Ocean bottom seismometer $\cdot$ Multichannel seismic reflection

\section{Introduction}

The Svalbard continental margin and the neighboring Knipovich Ridge have been extensively explored by use of seismic, seismological and other types of geophysical data (Fig. 1; Sundvor and Eldholm 1979; Myhre et al. 1982; Myhre 1984; Eldholm et al. 1987; Eiken and Austegard 1987; Crane et al. 1988; Austegard and Sundvor 1991; Crane et al. 1991; Faleide et al. 1996; Fiedler and Faleide 1996; Hjelstuen et al. 1996; Crane et al. 2001a, b; Ritzmann et al. 2002; Engen et al. 2003; Ljones et al. 2004; Ritzmann et al. 2004; Engen et al. 2008; Kandilarov et al. 2008). The earlier expeditions explored mainly the sedimentary cover and only the most recent ones, through the use of OBS, have brought some insight into the crustal structure. Only few crustal transects across this and other slow and ultra-slow spreading ridges exist worldwide.

In 2002 in a joint effort by the University of Bergen, Norway and Hokkaido University, Japan a survey was carried out to obtain two crustal profiles across the Knipovich Ridge, along presumed amagmatic and magmatic portions of oceanic crustal formation (Fig. 2). The crustal structure along the amagmatic profile was presented in Kandilarov et al. (2008) and revealed an interesting dependence between past spreading rate variations and crustal structure. In this paper we present results from the other profile over the presumed magmatic portion of oceanic crustal formation. To our knowledge, this is the first seismic wide-angle experiment performed along the spreading direction of both magmatic and amagmatic segments of any ultra-slow spreading ridge. 


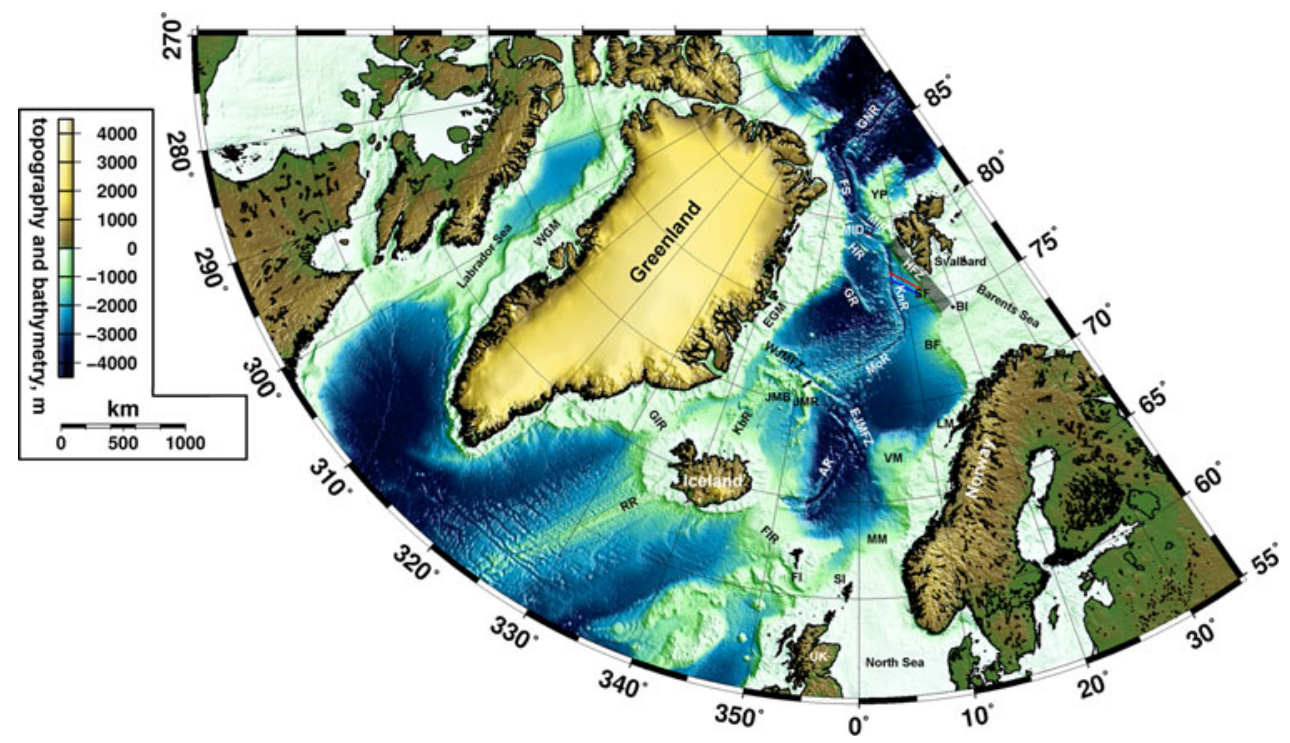

Fig. 1 Bathymetric map of the North Atlantic with the major features observable on the ocean floor with the profiles of Kandilarov et al. (2008) in red and the present study in blue. RR Reykjanes Ridge, GIR Greenland-Iceland Ridge, FIR Faeroe-Iceland Ridge, FI Faeroe Islands, SI Shetland Islands, $M M$ More Margin, $V M$ Voring Margin, $A R$ Aegir Ridge, EJMFZ East Jan Mayen Fracture Zone, WJMFZ West Jan Mayen Fracture Zone, KbR Kolbeinsey Ridge, JMR Jan

Decompression melting of mantle upwelling below the oceanic spreading ridges generates new oceanic crust. Over $90 \%$ of the global oceanic ridge system spreads with more than $15 \mathrm{~mm} /$ year generating $7 \pm 1 \mathrm{~km}$ thick crust (White et al. 1992). Above this spreading rate (ca. 15-20 mm/ year) there does not seem to exist a resolvable dependency between spreading rate and crustal thickness. Due to minimal heat losses the same amount of melt will be generated, which will generate crust with uniform thickness. Normal oceanic crust consists of an extrusive basaltic layer (Oceanic Layer 2) and a gabbroic layer (Oceanic Layer 3) (Grevmeyer and Weigel 1996). With time a sedimentary layer may be deposited on top of the magmatic crust (Oceanic Layer 1). For ridges spreading with less than $15 \mathrm{~mm} /$ year the conductive heat losses cause a decrease in melt production, which leads to generation of crust thinner than the global average as well as amagmatic segments where no crust is developed (Bown and White 1994; White et al. 1992; Dick et al. 2003).

\section{Geological history of the North Atlantic and the surveyed area}

\section{North Atlantic}

The Northern Mid Atlantic Ridge (NMAR) starts at ca. $60^{\circ} \mathrm{N}$ and ends at approx. $85^{\circ} \mathrm{N}$. It comprises the Reykjanes
Mayen Ridge, $J M B$ Jan Mayen Basin, EGM East Greenland Margin, WGM West Greenland Margin, MoR Mohns Ridge, GR Greenland Ridge, $B F$ Bjørnøya (Bear island) Fan, $B I$ Bear Island (Bjornoya), $S F$ Storfjorden Fan, HFZ Hornsund Fault Zone, HR Hovgaard Ridge, $K n R$ Knipovich Ridge, MlR Molloy Ridge, MlD Molloy Deep, FS Fram Strait, YP Yeremak Plateau, GNR Gakkel Nansen Ridge

Ridge, the Iceland hotspot, The Kolbeinsey, Mohns, Knipovich and Molloy Ridges (Fig. 1). Other conspicuous features on the ocean floor are the now extinct Aegir Ridge, the East and West Jan Mayen Fracture Zones, GreenlandSenja and Molloy Fracture Zones, Greenland-Iceland, Faeroe-Shetland, East Greenland and Hovgaard Ridges and the Spitsbergen and Hornsund Fracture Zones.

The North Atlantic Ocean evolved in two stages: in early Eocene (54.6 Ma ago) continental breakup occurred and sea floor spreading and generation of new oceanic crust started along the Reykjanes, Aegir and Mohns Ridges (Talwani and Eldholm 1977; Lundin and Doré 2002; Mosar et al. 2002a, b). Spreading along the Mid Atlantic and Arctic Ridges was coupled through the passive western Svalbard margin, comprising the Senja, Greenland and Hornsund Fracture Zones (Fig. 1). The second stage was initiated some $33 \mathrm{Ma}$ ago when the spreading in Labrador Sea stopped, the Greenland Plate became docked to the North American plate and the relative spreading direction changed from NNW-SSE to NW-SE. This event is recorded in the different orientation of the West and East Jan Mayen Fracture Zones (Mosar et al. 2002a, b). At that time the spreading center shifted from the Aegir Ridge to the Kolbeinsey Ridge and around $20 \mathrm{Ma}$ ago the former became extinct. The Northern Mid Atlantic Ridge propagated into the Spitsbergen Shear Zone and this created the Knipovich Ridge. Some ca. $23 \mathrm{Ma}$ ago spreading started along the Molloy Ridge and some 10.3 Ma ago it started 


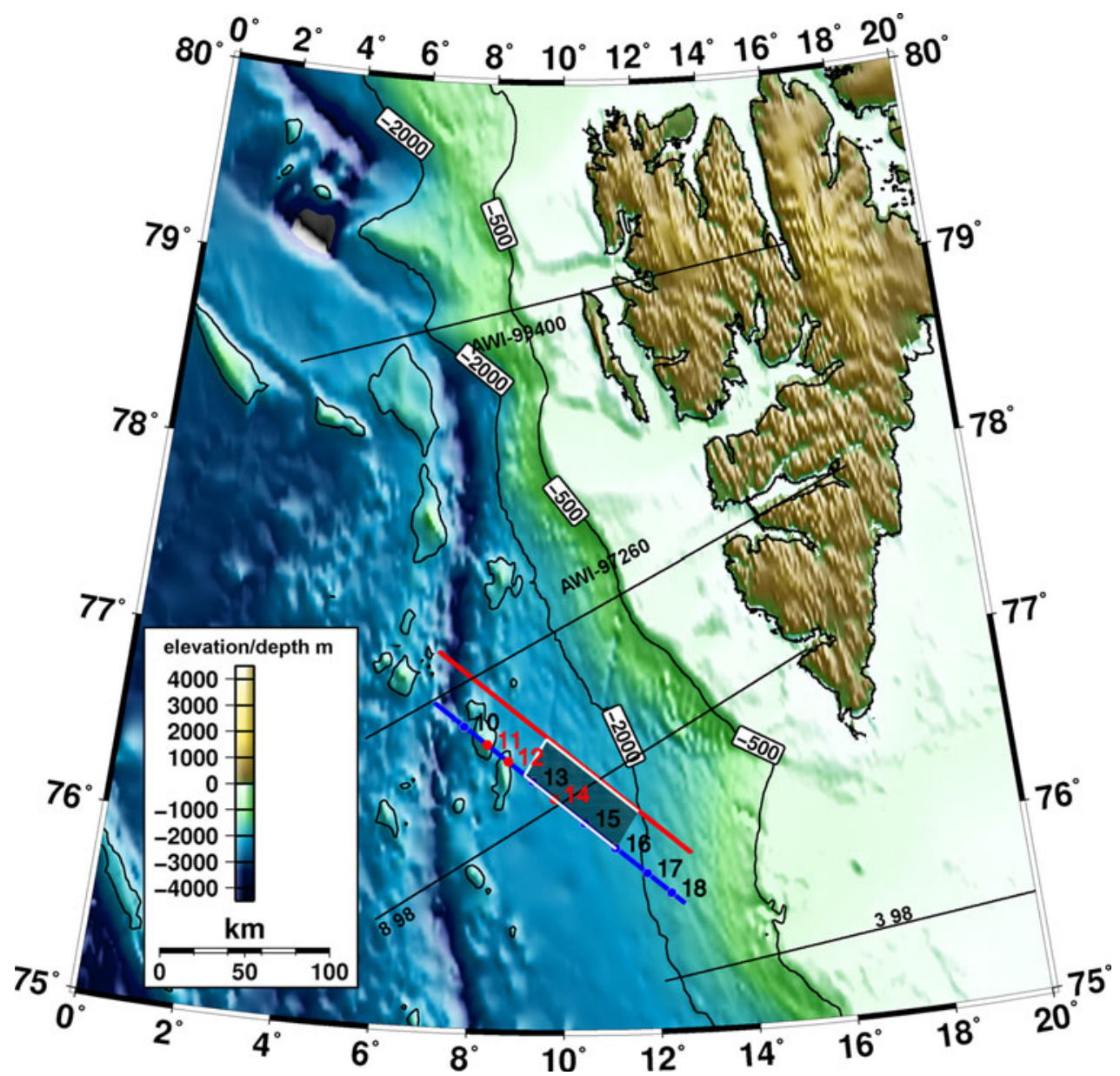

Fig. 2 Bathymetric map of the surveyed area, showing the line of this study (blue) and the instruments deployed along it. The blue numbers show the instruments that recorded useful data, the red numbers show the instruments that did not record data or were not recovered from the ocean floor. Other OBS profiles in the area are
Kandilarov et al. (2008) (red line), 8-98, Ljones et al. (2004), 3-98, Breivik et al. (2005), AWI-99400-Ritzmann et al. (2004), AWI97260-Ritzmann et al. (2002). The shaded white bordered polygon shows the onset and extent of a fault cutting from northwest to sowtheast down to the upper mantle along the Fram Strait, which established a connection between the Mid Arctic and the Northern Mid Atlantic Ridges (Crane et al. 1988, 1991; Ritzmann et al. 2002; Mosar et al. 2002a, b; Lundin and Doré 2002).

\section{The Knipovich Ridge}

The northernmost part of the Northern Mid Atlantic Ridge - the Knipovich Ridge—stretches from $\sim 73^{\circ} 50^{\prime}$, where it is joined to the Mohns Ridge, and ends some ca. $500 \mathrm{~km}$ northwards at approx. $78^{\circ} 30^{\prime}$ in the Molloy fracture zone (Fig. 2). The spreading direction is oblique to the plate boundary, which reflects the fact that the ridge has been created through propagation of the Northern MAR into the Spitsbergen shear zone ( $\sim 23$ Ma ago, Talwani and Eldholm 1977; Torsvik et al. 2001; Lundin and Doré 2002; Mosar et al. 2002a, b). Thermal modeling shows asymmetry in the spreading rate- to the west spreading occurs at $\sim 7 \mathrm{~mm} /$ year, while to the east it is $\sim 1 \mathrm{~mm} /$ year (Crane et al. 1988). This may be pointing to an eastward ridge migration or simply reflecting the fact that the North American plate moves faster than the Eurasian plate. The magnetic anomalies generated around the Knipovich Ridge are diffused (Fig. 3), possibly due to thermal blanketing from the thick sedimentary cover, broad zone of magma injection, high heat flow, fragmentation due to axial shifts in the past or several of those factors acting at the same time (Engen et al. 2003). The most critical factor, however, is the poor quality of the old magnetic data, the wide spacing between the lines and the bad positioning. The diffused pattern of the magnetic anomalies has precluded estimates of spreading rates from magnetic data (Myhre et al. 1982; Crane et al. 1988, 1991, 2001a; Dick et al. 2003). With the help of a recently acquired precisely navigated aeromagnetic dataset from the western Eurasia Basin (Brozena et al. 2003), the old magnetic data were 


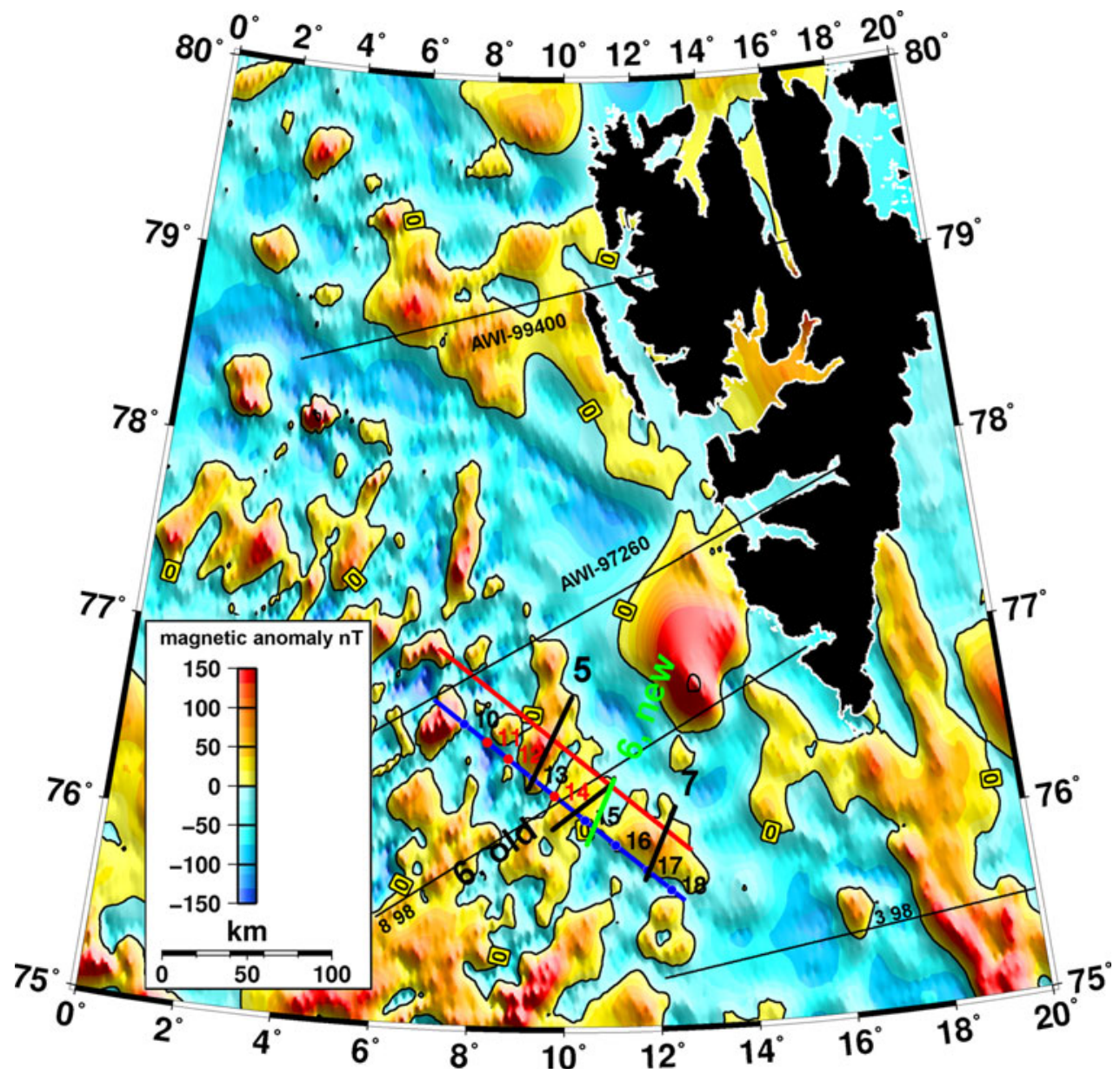

Fig. 3 Map of the magnetic field of the surveyed area with anomalies 5 and 7, in black, taken from Engen et al. (2008). The reinterpreted anomaly 6 is given in green together with the interpretation of Kandilarov et al. (2008), given in black. The black lines show the

corrected for navigation errors (Glebovsky et al. 2006) and were reprocessed and reinterpreted (Engen et al. 2008). This enabled the identification of several magnetic anomalies and confirmed the ultra-slow spreading nature (spreading rate $<12 \mathrm{~mm} /$ year, Dick et al. 2003) of the ridge. Kandilarov et al. (2008), using the work of Engen et al. (2008) and tentatively interpreting the position of magnetic anomaly 6 , inferred past variations in the spreading rate (between 5.5 and $8 \mathrm{~mm} /$ year to the east along their model). These values are higher than the value of $1 \mathrm{~mm} /$ year derived by Crane et al. (1988) from thermal modeling.

The Knipovich Ridge exhibits a 1,000-2,000 m deep rift valley with a seafloor depth ranging from 2,500 to $3,800 \mathrm{~m}$. The axial trace, as defined by the deep rift valley, is more or less continuous and shows no distinct offsets. Based on axial depth variations, however, the ridge may be divided into several $60-110 \mathrm{~km}$ long segments with topographic highs rising $500-1,000 \mathrm{~m}$ above the adjacent rift valley locations of OBS profiles from earlier studies, for details see Fig. 2. The red line shows the location of the OBS profile of Kandilarov et al. (2008)

floor. It is known that the volcanic most productive areas are typically regarded as the segment centers (see Cannat et al. 1995; Batiza 1996). In the case of Knipovich Ridge these topographic highs are associated with mantle Bouguer gravity minima and have been interpreted to represent areas with enhanced volcanic activity and thicker crust (Crane et al. 2001a, b; Okino et al. 2002; Hellevang and Pedersen 2005). This is consistent with new bathymetry data showing that young axial volcanic ridges define these centers. At the central and northern Knipovich Ridge, these axial topographic highs are associated with off-axis linear arrays of seamounts that are parallel to the flow line. These linear arrays suggest that the segmentation has been more or less stationary for at least 7-8 m/year (Hellevang and Pedersen 2005). The eastern flank of Knipovich Ridge is more subsided $(\sim 300 \mathrm{~m})$ with respect to its western counterpart, and this is usually attributed to the sedimentary load accumulated from the Svalbard Margin and Barents Sea (Crane et al. 1991; Faleide et al. 1996; Fiedler 
and Faleide 1996; Hjelstuen et al. 1996; Crane et al. 2001a).

Many studies report that the crust beneath slow and ultra-slow spreading ridges is anomalously thin ( $\sim 3.5-4.0 \mathrm{~km}$ ) with the main contribution coming from a thinned Oceanic Layer 3 (White et al. 1992; Klingelhofer et al. 2000; Klingelhofer and Geli 2000; Dick et al. 2003; Jokat et al. 2003). The crust within the median valley of the Knipovich Ridge is also anomalously thin $(\sim 3.5 \mathrm{~km})$ and reported seismic velocities in the crustal layers and upper mantle are very low (Oceanic Layer 2: $2.5-4.0 \mathrm{~km} / \mathrm{s}$, Oceanic Layer 3: 5.7-6.1 km/s, mantle 7-7.6 km/s) (Ritzmann et al. 2002; Ljones et al. 2004; Ritzmann et al. 2004; Kandilarov et al. 2008).

\section{Data acquisition and processing}

In 2002, the University of Bergen, Norway, in collaboration with Hokkaido University, Japan, carried out a survey for acquiring OBS, MCS and gravity data (using LaCoste Romberg gravity meter) along two parallel $190 \mathrm{~km}$ long lines, striking along the spreading direction (NW-SE) of the Knipovich Ridge. The first line was acquired $40 \mathrm{~km}$ north of a topographic high occurring at $\sim 76^{\circ} 30^{\prime} \mathrm{N}$. Based on the bathymetry available at this time we believed that underlying crust could be amagmatic. However, a study by Hellevang and Pedersen (2005) demonstrated the magmatic nature of the entire ridge segment. The first line, acquired along an assumed amagmatic portion of of oceanic crustal formation, was presented by Kandilarov et al. (2008). The second line, subject of the present paper, was acquired at the topographic high defining the segment center. Henceforth, we will refer to this as the segment center (SC) profile and to that of Kandilarov et al. (2008) as the off-segment-center (OSC) profile. The location of the two lines is shown in Fig. 2, together with the surveys reported in Ritzmann et al. (2002, 2004)Breivik et al. (2003), and Ljones et al. (2004).

The seismic source consisted of a six-airgun array with a total volume of 31.21 . The array was tuned in order to suppress the primary bubble pulse. The source was fired every $50 \mathrm{~m}$ at $7 \mathrm{~m}$ depth.

A total of nine-three component OBS instruments were deployed along the line but three instruments-OBSs 11, 12 and 14-did not record useful data. These are shown in red on the map (Fig. 2) while the stations that recorded useful data are shown in blue. The OBSs were developed at the Institute of Seismology and Volcanology, Hokkaido University, Sapporo and the Laboratory for Earthquake Chemistry, University of Tokyo. They consist of three orthogonally gimbal-mounted geophones-one vertical and two horizontal. The instruments can record continuously for approx. 14 days. The raw seismograms were prepared at Hokkaido University, Japan. Further processing was carried out at the University of Bergen, Norway. It was limited to velocity reduction $(8 \mathrm{~km} / \mathrm{s})$, bandpass filtering (3-5-12-17 Hz), predictive deconvolution with $60 \mathrm{~ms}$ prediction lag and $250 \mathrm{~ms}$ window length. Examples of the processed vertical component data are shown in Figs. 4c and $5 \mathrm{c}$. Data from the horizontal components was also used to make a $V \mathrm{p} / V \mathrm{~s}$ model. However, its resolution was much poorer compared to the $V \mathrm{p}$ model and we decided not to include it in this paper.

The MCS data were acquired with a $3 \mathrm{~km}$ long digital streamer (University of Bergen) kept at $10 \mathrm{~m}$ depth. The live section contains 240 recording groups that have $12.5 \mathrm{~m}$ of spacing. The recording length was $12 \mathrm{~s}$ and the sampling interval $2 \mathrm{~ms}$. The recording was done using $3 \mathrm{~Hz}$ low cut filter with a slope of $18 \mathrm{~dB} /$ octave and $180 \mathrm{~Hz}$ high cut filter with a slope of $72 \mathrm{~dB} /$ octave. The geometry setting and the processing of the generated MCS profile was carried out at the University of Bergen and consisted of a standard processing flow aimed at enhancing the detectability of the basement reflection and attenuation of multiples. The main processing steps included conversion from SEG-D to Seismic Unix format, resampling, geometry setting, bandpass filtering (5-10-100-120 Hz), f-k filtering, CMP sorting, velocity analysis, normal moveout (NMO), dip moveout correction (DMO), inverse NMO after DMO, velocity analysis after DMO, NMO after DMO, stacking, predictive deconvolution, migration, trace mixing and gain. Additional multiple attenuation was performed with the Radon transform, Cyclic Sampling and Median Filter analysis. The processed MCS section with interpretation of the basement reflector and the main reflecting interfaces indicated is shown in Fig. 6.

\section{Modeling procedures and uncertainties in the derived models}

P-wave modeling and modeling uncertainties

The interpreted MCS section was depth converted (Fig. 7) and used as a basis for modeling P-wave velocities. The forward and inversion 2-D kinematic raytracing modeling software RAYINVR was used in order to make the final Pwave velocity model shown in Fig. 8 (Zelt and Ellis 1988; Zelt and Smith 1992). This software requires that the velocity model be represented as a series of layers. The interfaces between the layers are described as series of nodes in the $\mathrm{X}-\mathrm{Z}$ space with $\mathrm{X}$ being the distance along the line, measured from the start of the model, and $\mathrm{Z}$, the depth of the node, respectively. The velocity field within each layer is given by a series of paired nodes in the $\mathrm{X}-\mathrm{V}$ space with $\mathrm{X}$ being the location of the node from the start of the 

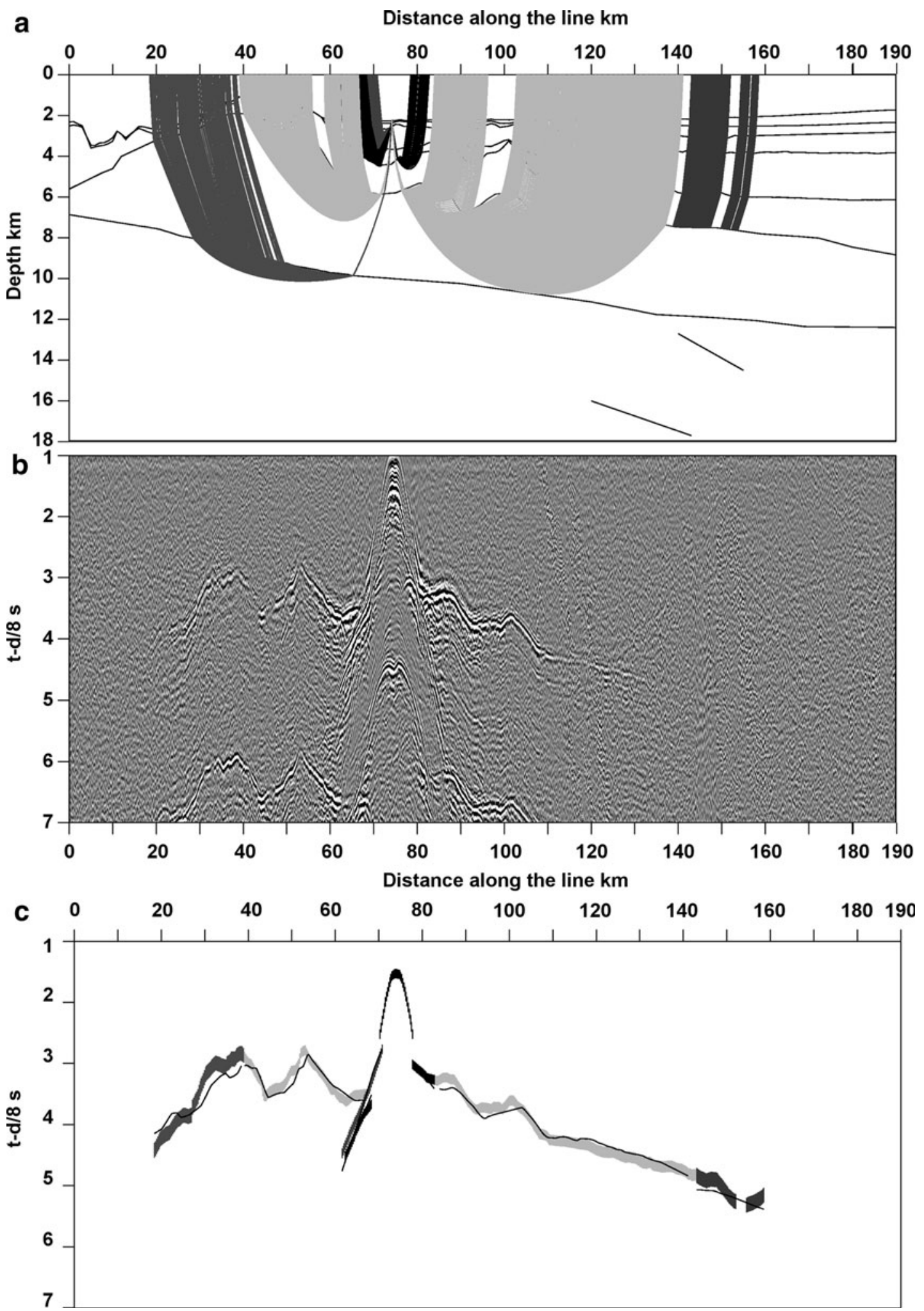

Fig. 4 a Ray tracing of P-waves trough the model for OBS 13; b the seismogram recorded on the vertical component of OBS 13. $\mathbf{c}$ The match between calculated (thin black lines) and observed (bars) travel times of P-waves propagating in the model for OBS 13 


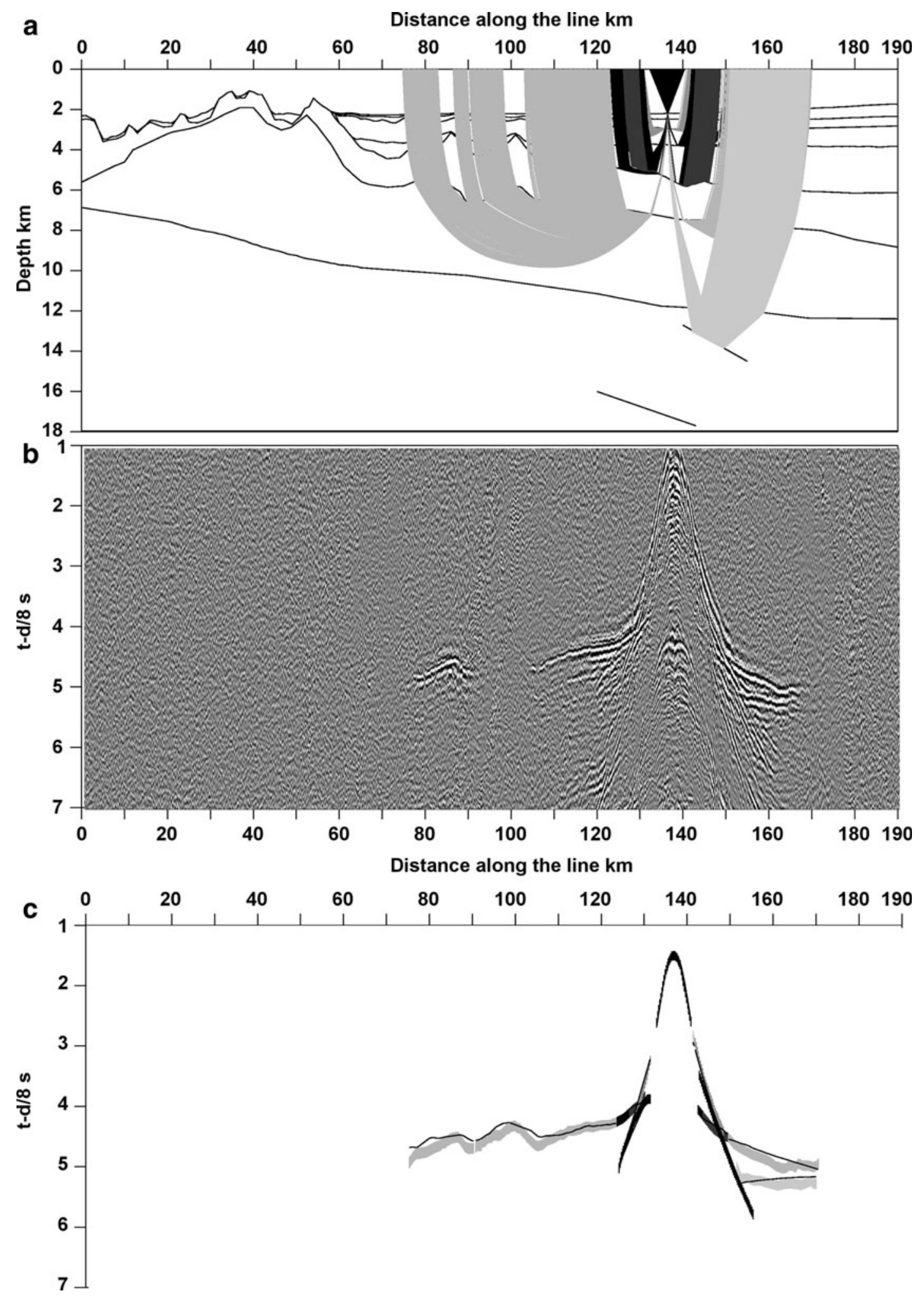

Fig. 5 a Ray tracing of P-waves trough the model for OBS 16; b the seismogram recorded on the vertical component of OBS 16. $\mathbf{c}$ the match between calculated (thin black lines) and observed (bars) travel times of P-waves propagating in the model for OBS 16 


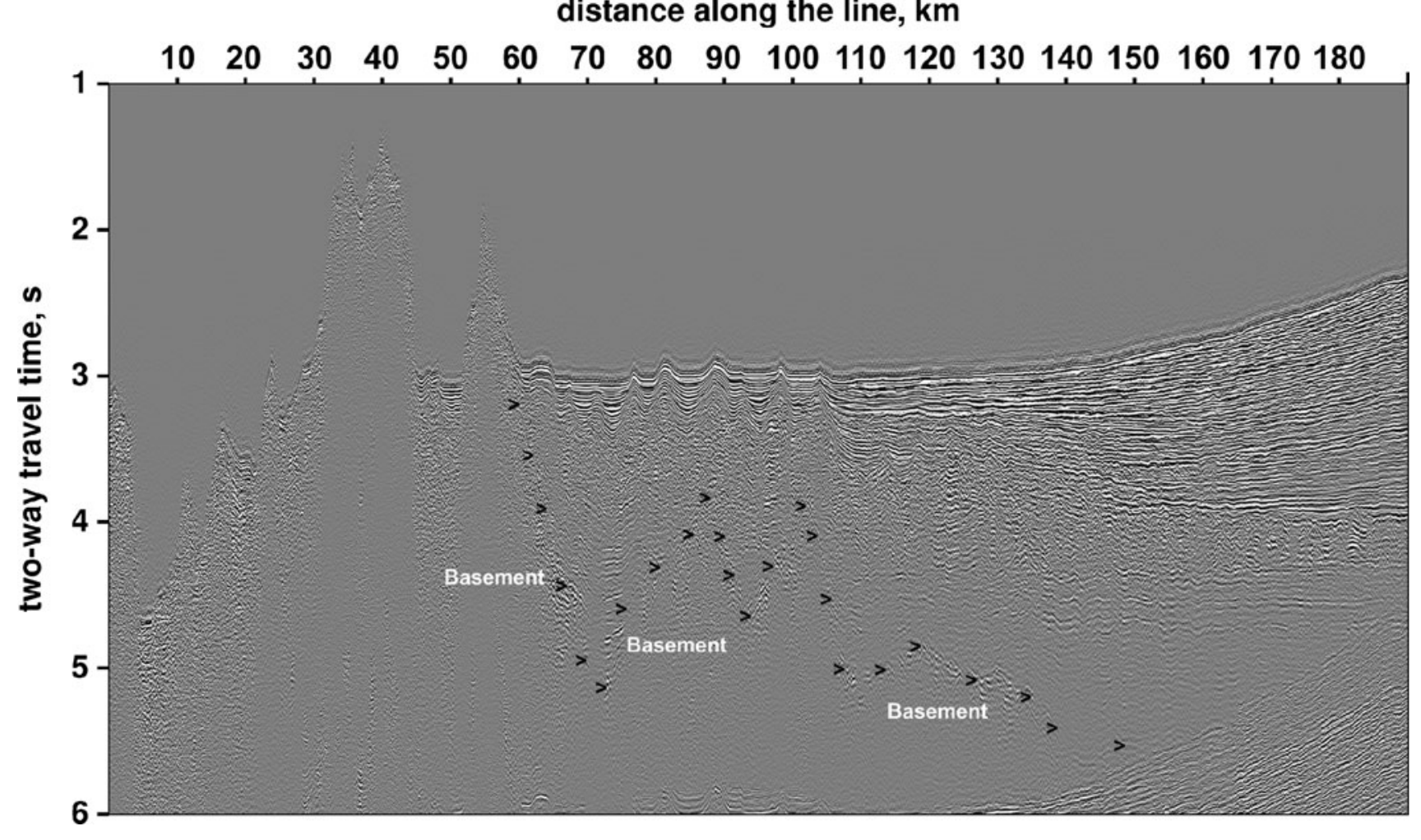

Fig. 6 Interpreted multichannel seismic section of the profile. The location of the basement reflection is shown with black arrows

model and $\mathrm{V}$-its velocity value. The depth of the coupled upper and lower velocity nodes is controlled by the top and bottom interfaces of the layer to which they belong. The velocity field between the nodes is made known through linear interpolation in vertical direction between the pairs of upper and lower nodes and linear interpolation in horizontal direction between neighboring nodes. A detailed description of the parametrization of the velocity model can be found in Zelt and Smith (1992).

In order to obtain a final velocity model from the preliminary model we need to interpret the clearest arrivals from the OBS data. The arrivals in the OBS seismogram represent records of the travel time curves of different types of seismic waves (refracted, reflected and head waves) propagating in the different layers of the model. The appearance of these curves will depend on the velocity structure. Due to different attenuation factors their sharpness will decrease with increasing distance from the instrument. This is taken into account by assigning picking uncertainty to the interpreted arrivals. For the present survey we chose linearly increasing uncertainty, which was set to $50 \mathrm{~ms}$ near the instrument and $100 \mathrm{~ms}$ at $190 \mathrm{~km}$ from the instrument. The raytracing software can compute theoretical travel time curves from the model. The final model is made by appropriately changing the parameters of the initial model until we obtain a satisfactory match between the calculated and observed travel times. The goodness of fit between the computations and observations is given numerically by calculating the $\chi^{2}$ value, estimated by the formula:

$$
\chi^{2}=\frac{1}{n} \sum_{i=1}^{n}\left(\frac{t_{0_{i}}-t_{c_{i}}}{U_{i}}\right)^{2}
$$

where $\mathbf{n}$ is the number of data points, $\mathbf{t}_{\mathbf{0} \mathbf{i}}$ is the observed and $\mathbf{t}_{\mathbf{c i}}$ is the calculated travel time of the $i$-th data point and $\mathbf{U}_{\mathbf{i}}$ is the travel time picking uncertainty of the $i$-th data point. A $\chi^{2}$ value around one means optimal fit between the observed and calculated travel times for the given uncertainty. However, out-of-plane ray paths, small-scale structural inhomogeneities and unresolvable small scale structures may prevent us from achieving ideal fit (Ljones et al. 2004; Mjelde et al. 2005; Kandilarov et al. 2008).

Fig. 7 a Detailed interpretation of the multichannel seismic section. The meaning of the colors is as follows: blue seabed, light purple GIII/GII (first scenario), dark purple GIII/GII (second scenario), violet $\mathrm{GII} / \mathrm{GI}$, orange $\mathrm{GI} / \mathrm{G} 0$, blue-green $\mathrm{G} 0 /$ basement; b-e rectangles showing enlarged areas from the interpreted MCS section discussed in the text 


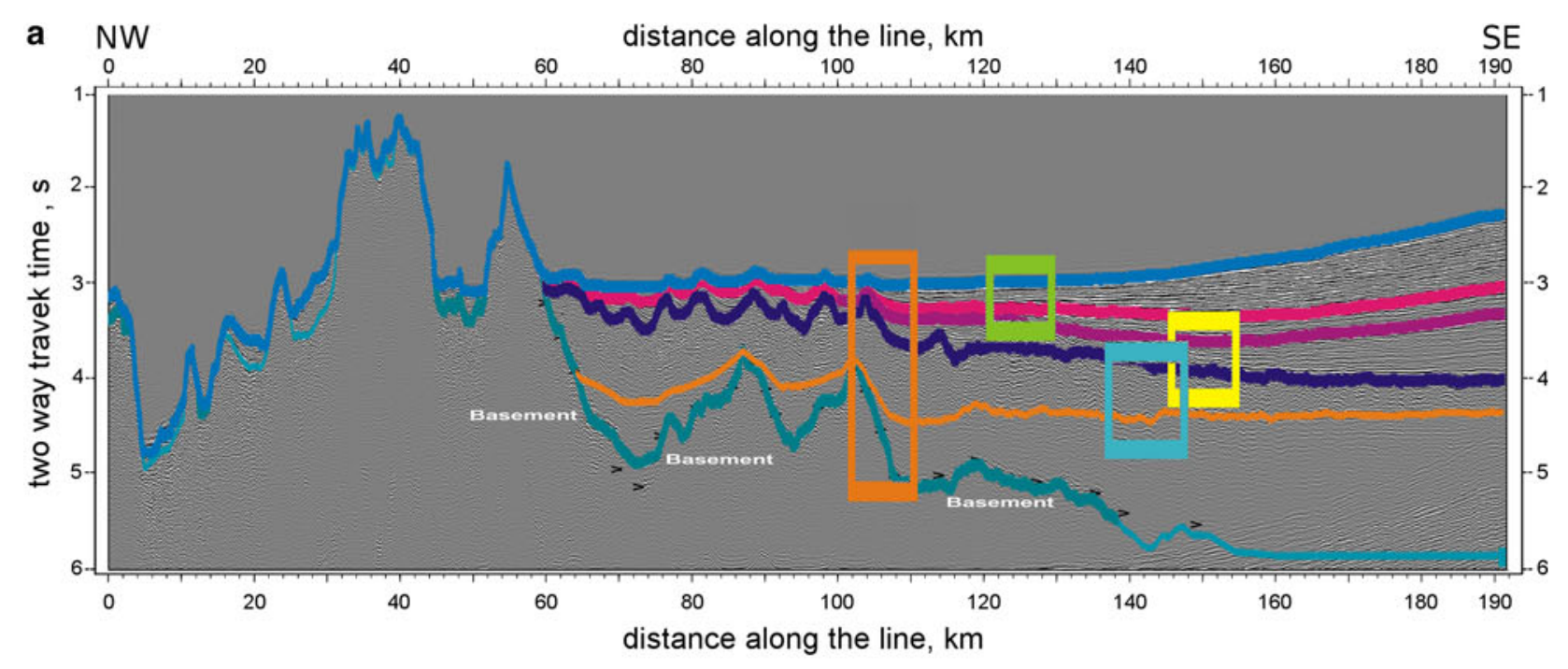

b

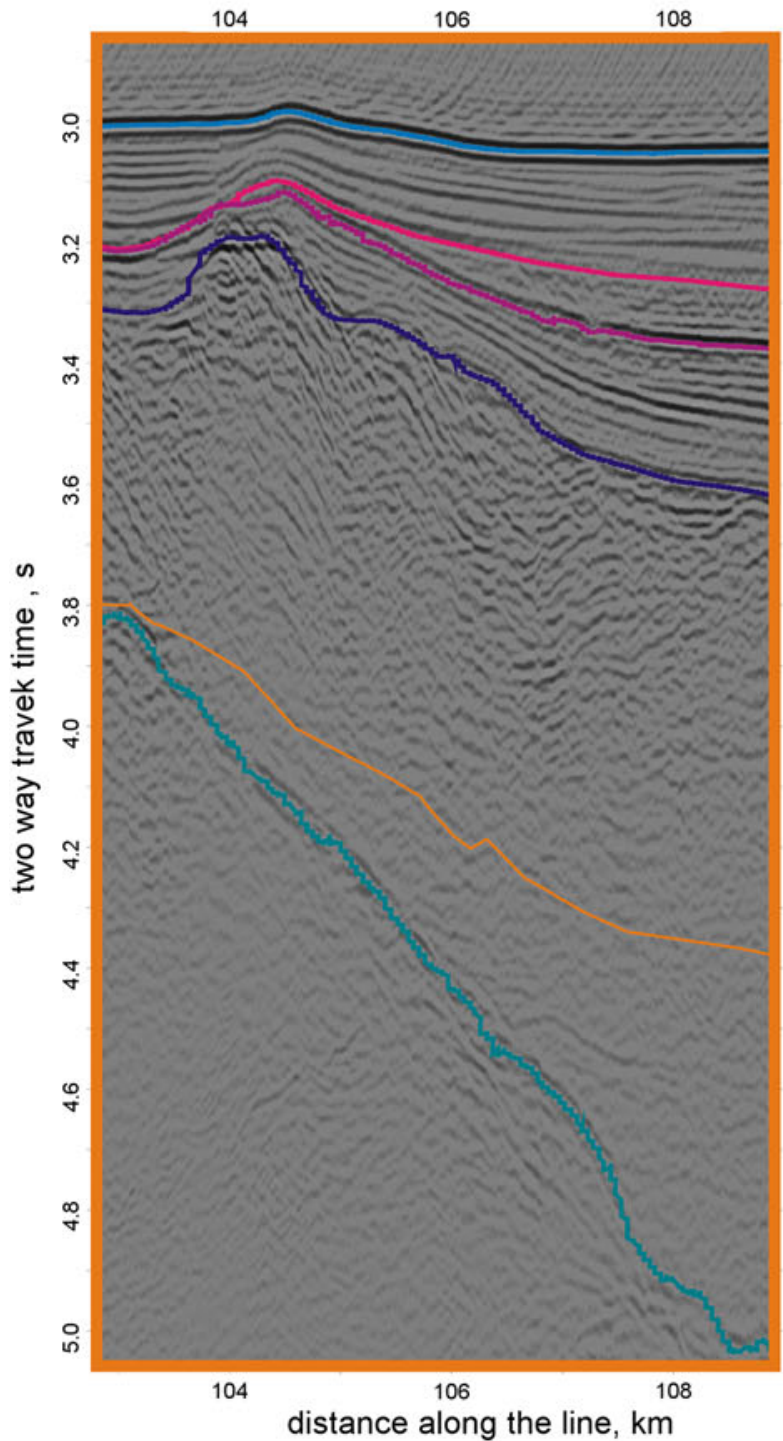

c distance along the line, $\mathrm{km}$
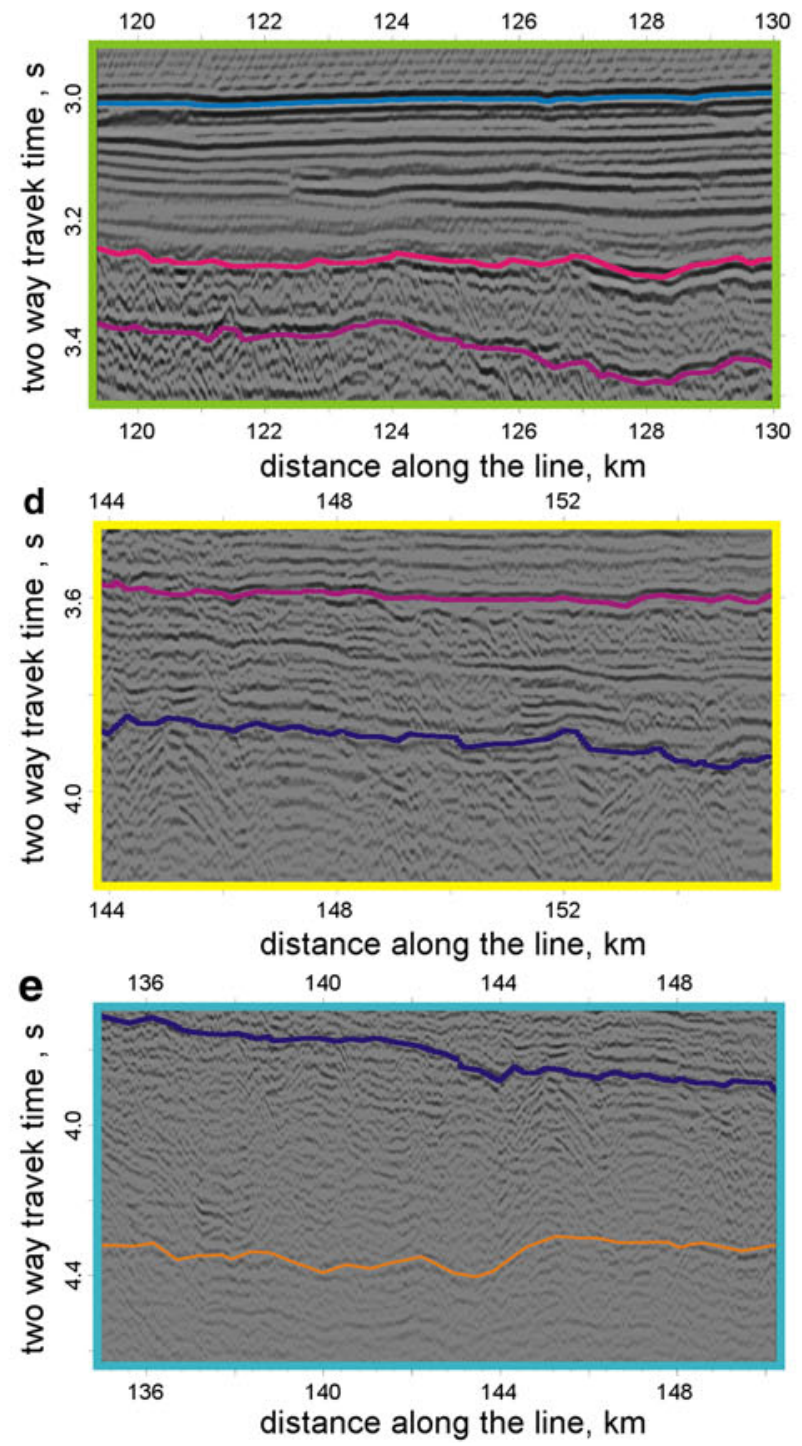


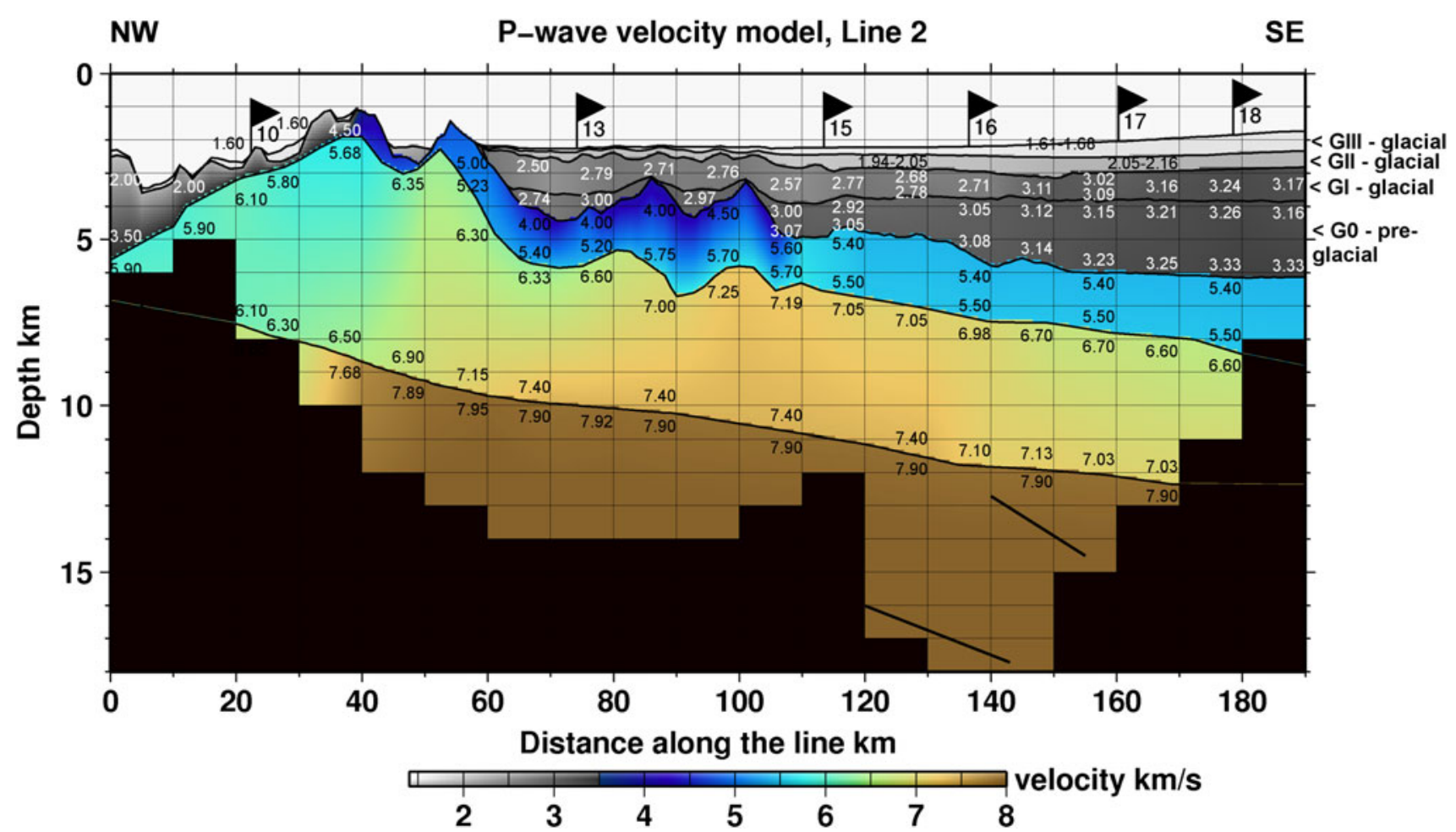

Fig. 8 Final P-wave velocity model. The blacked-colored section between $\sim 6$ and $\sim 18 \mathrm{~km}$ of depth corresponds to the non-illuminated part of the model. For the discussion see the text

We modeled from top to bottom starting with the topmost model layer. After achieving a satisfactory fit for the arrivals in this layer we continued downwards to model the parameters of the next layer. A more detailed discussion on different possible modeling strategies can be found in Zelt (1999) and Kandilarov et al. (2008).

The uniqueness, or uncertainty, of the final velocity model will depend on many factors but most of all on a satisfactory fit between the calculated and observed travel times and the data coverage of the interpreted dataset expressed as the number of rays penetrating the model (e.g. Zelt 1999; Breivik et al. 2002, 2003; Ritzmann et al. 2002; Ljones et al. 2004; Breivik et al. 2005; Kandilarov et al. 2008; Mjelde et al. 2008). We used these two indicators to assess the reliability of our models. The number of data points used to constrain the parameters of each layer and the $\chi^{2}$ and (Root-Mean-Square) RMS misfit values between the calculated and observed travel times are given in Table 1. The illumination diagram, shown in Fig. 9, gives a quantitative estimate of the ray density in our model. It shows which parts of the model have been covered by many rays and hence have been well resolved, and which have been poorly or not at all penetrated by seismic waves and hence remain unresolved. The diagram was obtained by dividing the model into $10 \times 1 \mathrm{~km}$ rectangular cells
Table 1 Number of data points used to constrain the interfaces and velocity structure of the P-wave model in each layer with their respective RMS travel time residuals and $\chi^{2}$ misfit

\begin{tabular}{llll}
\hline Layer & $\begin{array}{l}\text { Number of } \\
\text { data points }\end{array}$ & RMS & $\chi^{2}$ \\
\hline Mantle & 1,003 & 0.120 & 1.848 \\
OL3 & 1,513 & 0.109 & 1.713 \\
OL2 & 120 & 0.067 & 0.762 \\
G0 & 172 & 0.062 & 0.634 \\
GI & 327 & 0.109 & 1.946 \\
GIII-GII & 86 & 0.070 & 0.814 \\
Total & 3,221 & 0.108 & 1.635 \\
\hline
\end{tabular}

and calculating the number of rayhits in each cell as a percentage of the total number of rayhits in the model. The total number of $10 \times 1 \mathrm{~km}$ cells in the model is thus 342 and it contains all $(100 \%)$ rayhits. Therefore, if our model were equally illuminated, each rectangular cell would contain the same percentage of rayhits or $0.29 \%$ of the total number of rayhits $(100 \% / 342 \approx 0.29 \%$, Kandilarov et al. 2008). Therefore, we consider parts of the model, illuminated by at least $0.29 \%$ of rayhits, to be well resolved.

The uncertainty in the shallow part of the model will depend on the uncertainty of the interpretation of the MCS 


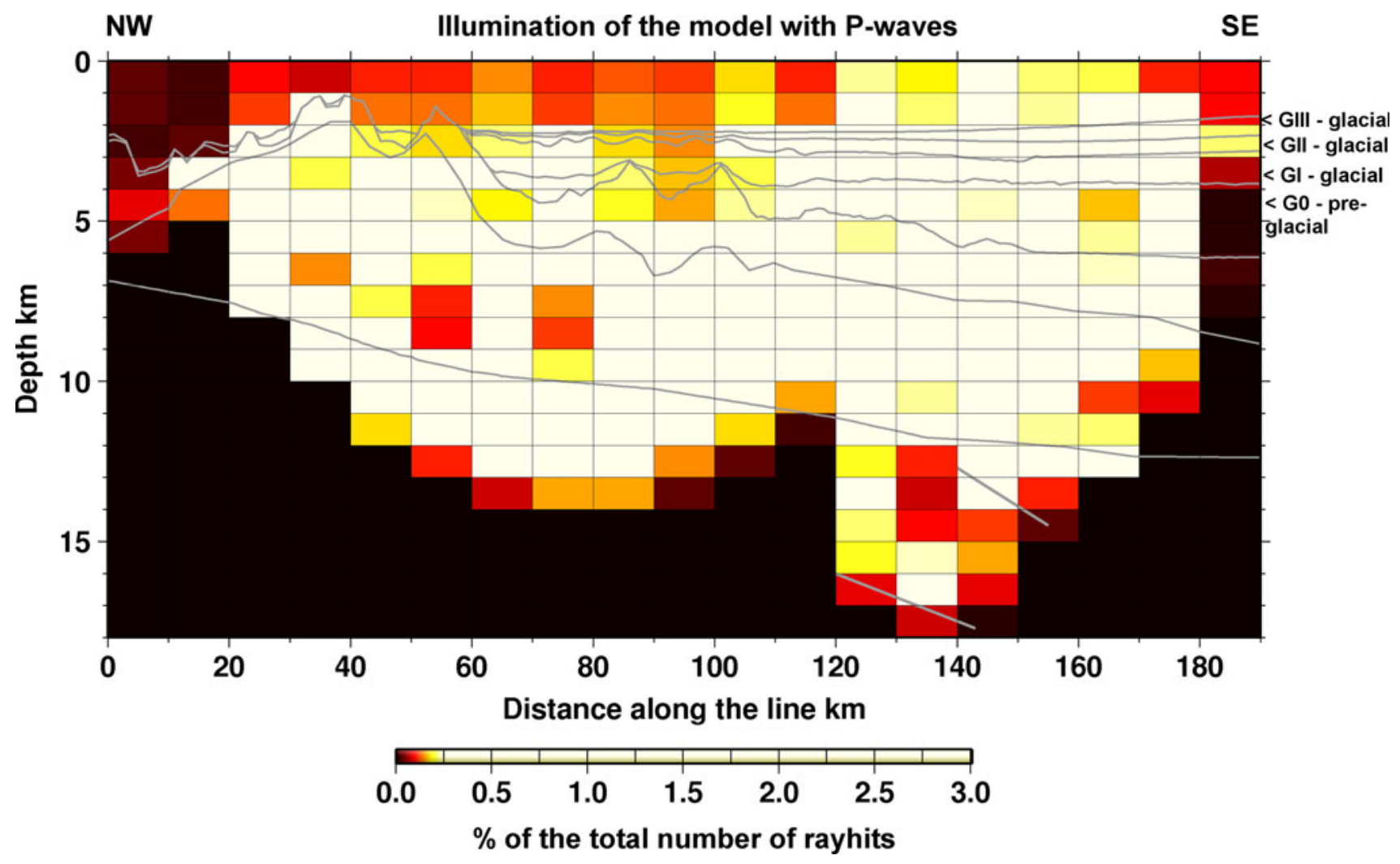

Fig. 9 Illumination of the P-wave model

section but the major impact will come from the precision with which we know the seismic velocities in the interpreted formations that are used for depth conversion. In this model we used velocities taken from the neighboring profile reported by Kandilarov et al. (2008). Due to the proximity of the two lines, the velocities in the sediments should be similar. The raytracing showed that minor adjustment was needed only for the middle part of our model. From the illumination diagram in Fig. 9 and Table 1 one can see that the sediments are properly illuminated and modeled. The estimated velocity uncertainty for the sediments is $\pm 0.1 \mathrm{~km} / \mathrm{s}$ and the depths of the sedimentary interfaces are resolved to within $\pm 0.3 \mathrm{~km}$.

Because the deeper part is known only from modeling the OBS data, the level of uncertainty of the model will depend primarily on the correct interpretation of these data, the picking uncertainty and the availability of far-offset arrivals. The instruments have registered enough clear faroffset arrivals to allow us to adequately model the velocity structure of the deeper layers (Figs. 4, 5). This is also reflected in the illumination diagram Fig. 9 and Table 1. The interfaces in the crustal part of the model $(4.5-13 \mathrm{~km})$ are resolved within $\pm 1.0 \mathrm{~km}$ and the velocities within $\pm 0.2 \mathrm{~km} / \mathrm{s}$.
Gravity modeling and modeling uncertainties

In order to have an independent constraint on the crustal structure we performed gravity modeling making use of the gravity dataset collected during the survey (Holbrook et al. 1994; Mjelde et al. 1998, 2005; Raum et al. 2002). The gravity model is described as a number of polygons, their horizontal sides being along the interfaces of the layers of the final velocity model and their vertical sides being specified by the user and usually taken along the higher lateral velocity gradients within each layer. Depending on the average $\mathrm{Vp}$ each polygon is assigned a certain density, which is taken initially from a standard empirical Vpdensity relationship found in Ludwig et al. (1970). After adjusting the densities in the polygons we calculated the theoretical gravity field using the 2.5-D interactive modeling program GRAVMAG (Pedley 1993) and compared it with the gravity field measured during the survey, aiming to get the best possible fit. The final gravity model and the calculated vs observed gravity fields are shown in Fig. 10. A summary of the density model is given in Table 3.

The gravity model will inherit the uncertainties of the velocity model because it uses it as a basis. Additional uncertainty in the gravity model comes from averaging 
Fig. 10 a Observed (black) versus calculated (blue) gravity field from the gravity model; b gravity-depth model along the surveyed profile

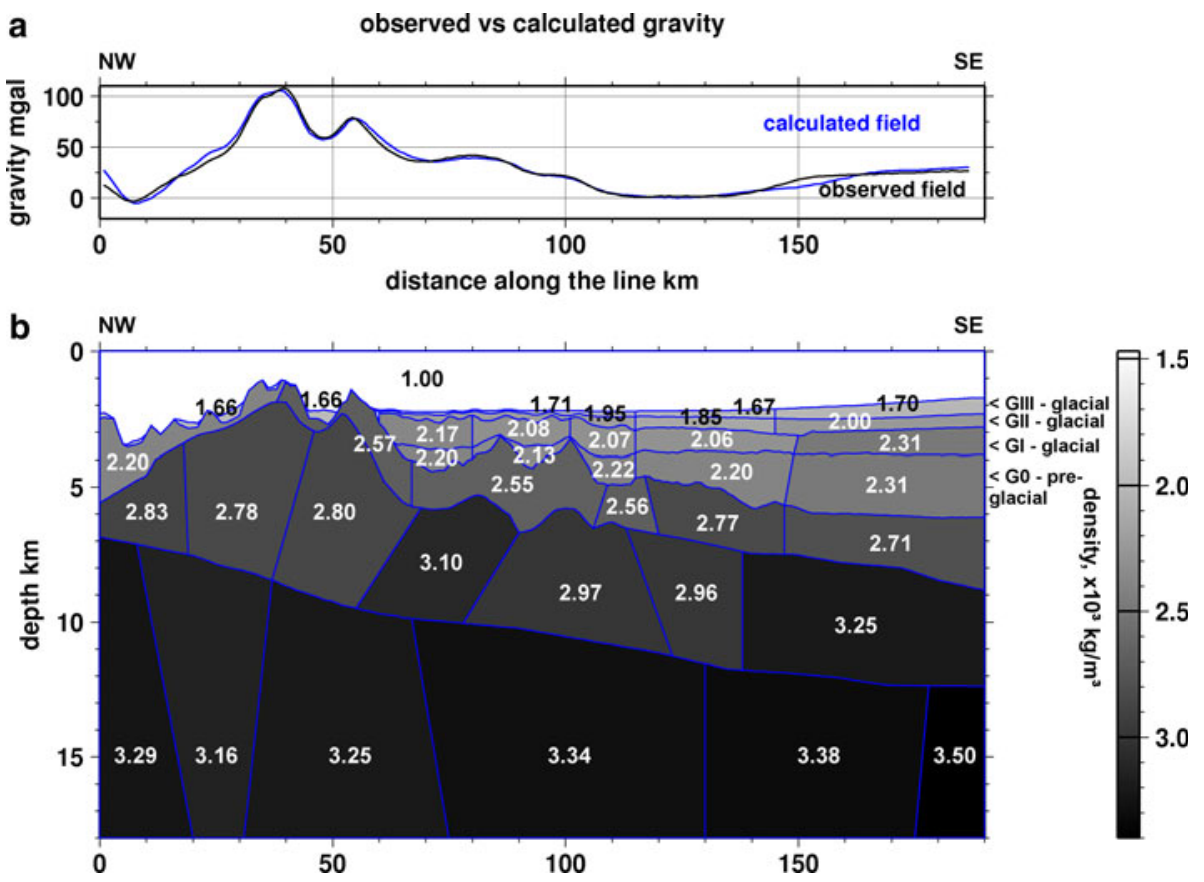

the seismic velocity within each polygon, in order to assign a single density value. For addressing the latter issue we may introduce more polygons but this will lead to an overparametrized model, but not necessarily a better one. Offline effects, which will be present in this ridge setting, cannot be modeled with this software.

\section{Results}

\section{MCS data}

The uninterpreted MCS section is given in Fig. 6. A part of the interpreted seismic section used for making the preliminary OBS model is shown in Fig. 7. We identified glacial sequences GIII to GI and the pre-glacial sequence G0. This division is based on the description of the sequences' seismic signatures that are found in Fiedler and Faleide (1996), Faleide et al. (1996) and Hjelstuen et al. (1996). Hjelstuen et al. (1996) have further established the presence of seven regional reflections in the area, named $\mathrm{R} 1$ to R7 from top to bottom. Reflection R1 separates GIII and GII and its age has been estimated at $0.44 \mathrm{Ma}$. Reflection R5 has been estimated to be approx. 1.0 Ma old and separates sequences GII and GI. The oldest reflection is R7 (ca. 2.3 Ma) and it separates sequences GI and G0. Identifying those formations was necessary in order to be able to compare our results with the results of Kandilarov et al. (2008) and Ljones et al. (2004). Sequences GIII and GII are described as varying between continuous Reflections and chaotic seismic character depending on the position relative to a depositional fan system discussed in Fiedler and Faleide (1996), Faleide et al. (1996) and Hjelstuen et al. (1996). Continuous reflections are found on the distal fan and a more chaotic seismic pattern is found closer to the slope. Sequence GI is described as chaotic with discontinuous internal reflections in an area neighboring the survey site discussed in this paper. G0 is characterized by discontinuous parallel to sub-parallel reflections (Hjelstuen et al. 1996; Faleide et al. 1996; Fiedler and Faleide 1996).

The identified sequences GIII and GII are, in general, continuous Reflections with a somewhat more chaotic seismic pattern in some areas (Fig. 6). The interface between sequences GIII and GII separates the lower sequence, with a more disturbed seismic pattern, from the upper one, with a more continuous pattern (Fig. 7b). From the ENE of the model to $\sim 105 \mathrm{~km}$ this reflection is easily to follow, but further away we hesitated between two different alternatives, which are given in Fig. $7 \mathrm{a}, \mathrm{b}$ and $\mathrm{c}$ with dark and light purple line, respectively. The two-way travel time difference between both alternatives is almost constant-around $250 \mathrm{~ms}$. The reflection of the lower interpretation (dark purple line) is more coherent compare to its neighbors. This is not the case for the upper alternative (light purple line), where the interpreted reflection is amidst other reflections with similar amplitude. Therefore, we decided to include the former interpretation (lower reflection, dark purple line) in the preliminary OBS model and discarded the latter (the upper reflection, light purple line).

The G0 and GI sequences have quite similar seismic patterns (Fig. 7d, e). The GII-to-GI and GI-to-G0 
reflections are both very clear along the entire profile. The GI-to-G0 reflection is touching the basement reflection at $\sim 85 \mathrm{~km}$ and $\sim 100 \mathrm{~km}$. The basement Reflection (top igneous crust) is strong and coherent and is easily followed from the beginning of the profile to $\sim 150 \mathrm{~km}$. Further away it becomes buried in the sea bottom multiple (Fig. 6).

P-wave and gravity models

The final P-wave velocity model is shown in Fig. 8. It has been made after raytracing the interpreted OBS data (Figs. 4, 5) and adjusting the seismic velocities and the interfaces of the different layers of the preliminary P-wave velocity model. The final model fits optimally the maximum possible amount of interpreted OBS data.

\section{Sedimentary section}

The sedimentary portion of the model consists of the glacial sequences GIII-GI and the pre-glacial sequence G0 (Faleide et al. 1996; Fiedler and Faleide 1996; Hjelstuen et al. 1996; Ljones et al. 2004). In the first $60 \mathrm{~km}$ of the profile the sedimentary cover is discontinuous and present as several sedimentary sub-basins with thickness varying between 0.1 and $0.4 \mathrm{~km}$ and seismic velocity of $\sim 1.6 \mathrm{~km} / \mathrm{s}$. A continuous sedimentary cover is observed from $\sim 60 \mathrm{~km}$ from the WNW end of the profile to its ESE end, where the cover is thicker $(\sim 4.3 \mathrm{~km})$. Exceptions are the two basement highs at $\sim 85$ and $\sim 100 \mathrm{~km}$ where the sedimentary cover is thinner $(\sim 1.00 \mathrm{~km})$. Generally, the modeled seismic velocities and densities increase with thickness and depth (Figs. 10, 13). Additional far-offset sedimentary arrivals are traced through the model for the instruments located further away from the ridge (over thicker sedimentary cover).

Sequence GIII is observed from ca. $60 \mathrm{~km}$ from WNW end of the line to its ESE end (Fig. 8). No rays diving or being reflected directly within the sequence is illuminating this layer. Instead, it is rays going deeper and penetrating the layer on their ascent or descent that are causing the illumination. At several places between $\mathrm{km} \sim 60$ and $\sim 105$, the layer thins out and almost disappears. From $\sim 105 \mathrm{~km}$ to the end of the model the thickness of GIII increases from about $0.25-0.6 \mathrm{~km}$. The modeled seismic velocities of the layer only vary slightly from $1.6 \mathrm{~km} / \mathrm{s}$ at $\sim 60 \mathrm{~km}$ to $1.7 \mathrm{~km} / \mathrm{s}$ at the SE end of the model. In the gravity model (Fig. 10) sequence GIII has low modeled density (Table 3).

From $\sim 60$ to $190 \mathrm{~km}$ sequence GII is present and continuous (Fig. 8). Between $\sim 60$ and $\sim 105 \mathrm{~km}$ its thickness does not vary significantly $(0.15-0.3 \mathrm{~km})$ and is on average around $0.2 \mathrm{~km}$. Southeastwards of $\mathrm{km} 105$ the thickness of GII is almost constant $(\sim 0.4 \mathrm{~km})$. The only exception is a thickening of the layer $(0.6 \mathrm{~km})$ at $\sim 150 \mathrm{~km}$, which is due to a local low in the interface between GII and GI. The modeled seismic velocity in GII slightly decreases from $2.1 \mathrm{~km} / \mathrm{s}$ at the beginning of the formation to $1.9 \mathrm{~km} / \mathrm{s}$ at ca. $110 \mathrm{~km}$, and from there to the end of the profile it gradually increases to $2.2 \mathrm{~km} / \mathrm{s}$. The modeled density of GII generally follows the velocity trend (Fig. 10; Table 3).

Sequence GI stretches from approx. $60-190 \mathrm{~km}$. Its thickness varies between 0.6 and $1.2 \mathrm{~km}$ (Fig. 8). From the beginning of GI at $\sim 60$ to $\sim 80 \mathrm{~km}$ the seismic velocity increases from 2.5 to $2.8 \mathrm{~km} / \mathrm{s}$ and from $\sim 80$ to $\sim 150 \mathrm{~km}$ it varies over a small range (i.e. $2.6-2.7 \mathrm{~km} / \mathrm{s}$ ). From ca. $150 \mathrm{~km}$ to the SE end of the model the seismic velocity is higher than $3.0 \mathrm{~km} / \mathrm{s}$ and varies in the range $3.0-3.2 \mathrm{~km} / \mathrm{s}$. The density in GI gently increases in NW-SE direction (Fig. 10; Table 3).

Sequence G0 extends from $\sim 65 \mathrm{~km}$ to the end of the model (Fig. 8). Topographic highs of the top of the basement pierce this layer at $\sim 85$ and $\sim 100 \mathrm{~km}$ and divide it into three unequal parts. In the section between 60 and $85 \mathrm{~km}$ the maximum thickness is $\sim 0.75 \mathrm{~km}$ and the seismic velocity varies between 2.7 and $3.00 \mathrm{~km} / \mathrm{s}$. In the section ranging from 85 to $100 \mathrm{~km}$ the maximum layer thickness is $0.8 \mathrm{~km}$ and the seismic velocity is $\sim 3 \mathrm{~km} / \mathrm{s}$. In the last section, i.e. from 100 to $190 \mathrm{~km}$, the layer's thickness gradually increases from 1.0 to $\sim 2.5 \mathrm{~km}$. The seismic velocities vary between $2.9 \mathrm{~km} / \mathrm{s}$ at ca. $100 \mathrm{~km}$ to $3.3 \mathrm{~km} / \mathrm{s}$ at the end of the model. The velocity variation pattern also correlates with the gravity model (Fig. 10; Table 3).

\section{Igneous crust}

The igneous crust has been interpreted as Oceanic Layer 2 and Oceanic Layer 3 (Fig. 8). The thickness and average seismic velocity variations along the line for the two layers are shown in Fig. 11a. The available data did not provide enough evidence to allow us to properly resolve Oceanic Layers 2 and 3 into Oceanic Layers $2 \mathrm{~A} / 2 \mathrm{~B}$ and $3 \mathrm{~A} / 3 \mathrm{~B}$, respectively. A possible reason is the sparse instrument coverage after the loss of OBSs 11, 12 and 14.

Oceanic Layer 2 is illuminated with rays almost along the entire length of the model (Figs. 10, 12a). However, its northwestern half $(0-70 \mathrm{~km})$ is sampled indirectly by waves in the deeper layers which pass through it. Few diving rays have directly sampled the layer between ca. 70 and $190 \mathrm{~km}$. Only the southeastern end (i.e. 180-190 km) of the basal portion of this layer was not illuminated by the seismic waves. Information for the non-illuminated portion of that interface is available from the gravity model (Fig. 10). The thickness of Oceanic Layer 2 rapidly drops from $\sim 3 \mathrm{~km}$ at the rift axis to less than $1 \mathrm{~km}$ at approx. 


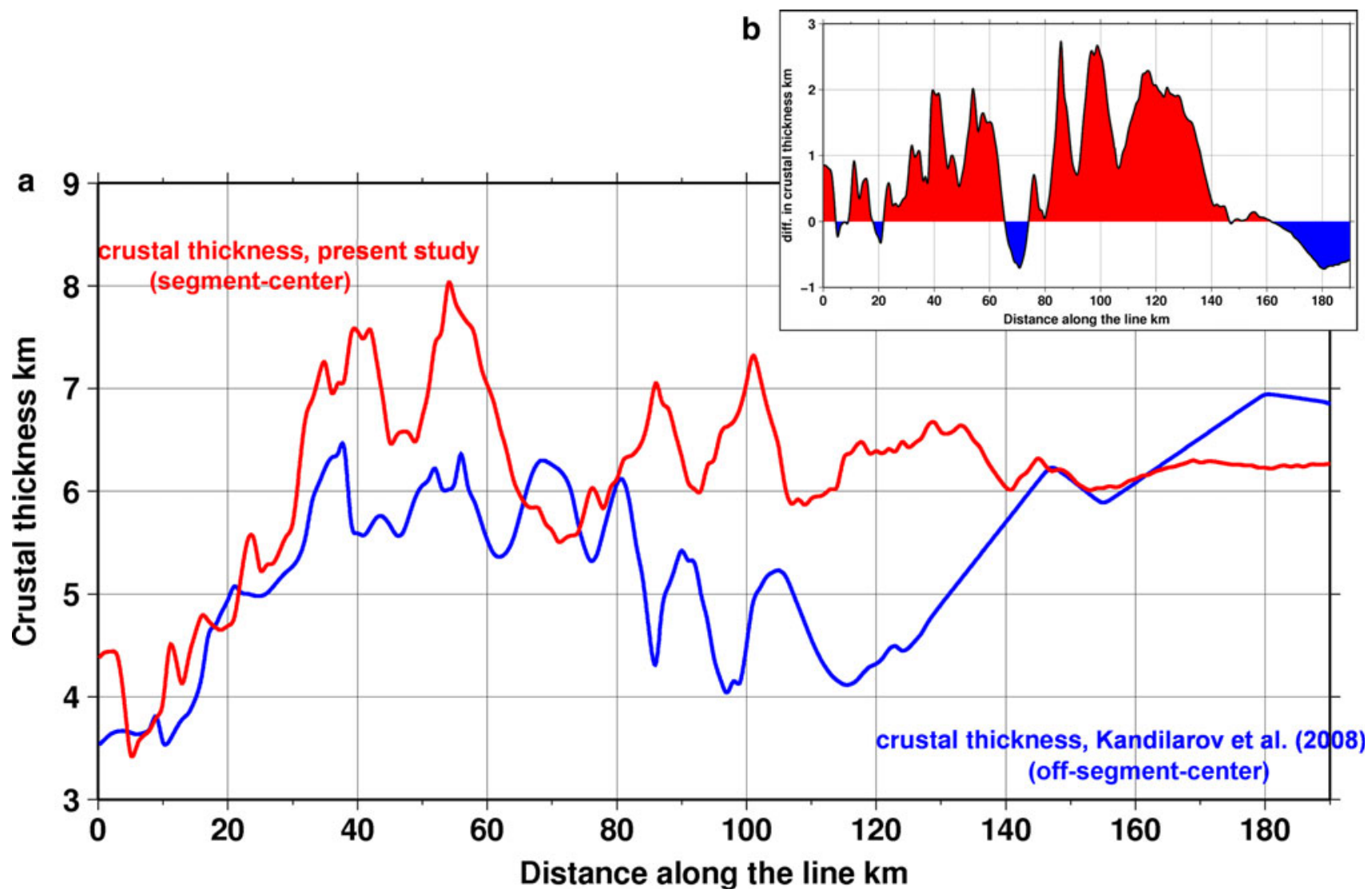

Fig. 11 a Variation along the line of the total modeled crustal thickness for the our model (blue line) and for the model of Kandilarov et al. (2008) (red line); b difference between the total modeled crustal thickness for the present model and the model of Kandilarov et al. (2008)

$15 \mathrm{~km}$ (Fig. 12). In the section between 15 and $55 \mathrm{~km}$ the thickness of Oceanic Layer 2 fluctuates in the range of $0.2-1.0 \mathrm{~km}$ with an average of $0.5-0.6 \mathrm{~km}$. Between ca. 55 and $\sim 85 \mathrm{~km}$ the layer is $\sim 1.7 \mathrm{~km}$ thick on average. From $\sim 85$ to $\sim 105 \mathrm{~km}$ the layer is thicker than $2 \mathrm{~km}$ and from $\sim 105 \mathrm{~km}$ to the SE end of the model the thickness is almost constant $\sim 2 \mathrm{~km}$ although some slight variations are observed (Fig. 12).

A low seismic velocity of $\sim 2.8 \mathrm{~km}$ characterizes Oceanic Layer 2 in the section between 0 and $30 \mathrm{~km}$ (Fig. 12). Southeastwards of $\sim 30 \mathrm{~km}$ the velocity increases to more than $5 \mathrm{~km} / \mathrm{s}$. Between ca. 60 and $\sim 110 \mathrm{~km}$ there is a decrease in the velocity trend along the line with a minimum at approx $80 \mathrm{~km}$ where the $V \mathrm{p}$ is $4.6 \mathrm{~km} / \mathrm{s}$. From $110 \mathrm{~km}$ to the end of the model the modeled average seismic velocity in Oceanic Layer 2 is constant and equal to $5.5 \mathrm{~km} / \mathrm{s}$. The gravity model does not repeat the trend of the average seismic velocity along the line (Fig. 10; Table 3).

Except for the SE end of the model (180-190 km), the top of Oceanic Layer 3 is imaged by OBS data along its entire length (Figs. 10, 12). The missing information was again taken from the gravity model (Fig. 10). In our model Oceanic layer 3 begins as a thin layer $(<2 \mathrm{~km})$ but it rapidly thickens and reaches a local thickness maximum of $6.8 \mathrm{~km}$ at the first magmatic high located at $40 \mathrm{~km}$ (Fig. 12). Between the two off-axial magmatic highs, there is a local minimum $(\sim 45 \mathrm{~km})$ where the thickness reaches $\sim 6 \mathrm{~km}$. At the second off-axial magmatic high at $\sim 52 \mathrm{~km}$ the layer reaches a maximum thickness of $7.1 \mathrm{~km}$. Further away the thickness rapidly decreases to an average value of $\sim 4-4.8 \mathrm{~km}$. There is a reverse proportionality in the thickness trends of Oceanic layers 2 and 3 (Fig. 12) in sections ranging from $\sim 5$ to $60 \mathrm{~km}, \sim 75$ to $90 \mathrm{~km}$ and $\sim 90$ to $110 \mathrm{~km}$. The seismic velocity trend along Oceanic Layer 3 is described by a gentle curve (Fig. 12). From 0 to ca. $40 \mathrm{~km}$ the P-wave seismic velocity in Oceanic Layer 3 is almost constant and around $6 \mathrm{~km} / \mathrm{s}$. From there to $100 \mathrm{~km}$ the velocity steadily increases to $7.3 \mathrm{~km} / \mathrm{s}$ and from that point to the end of the model it slowly decreases to $6.9 \mathrm{~km} / \mathrm{s}$. The density of Oceanic Layer 3 in the first $55 \mathrm{~km}$ is relatively low compared to the density of the adjacent area (approx 55-85 km) (Fig. 10; Table 3). At the SE end of 

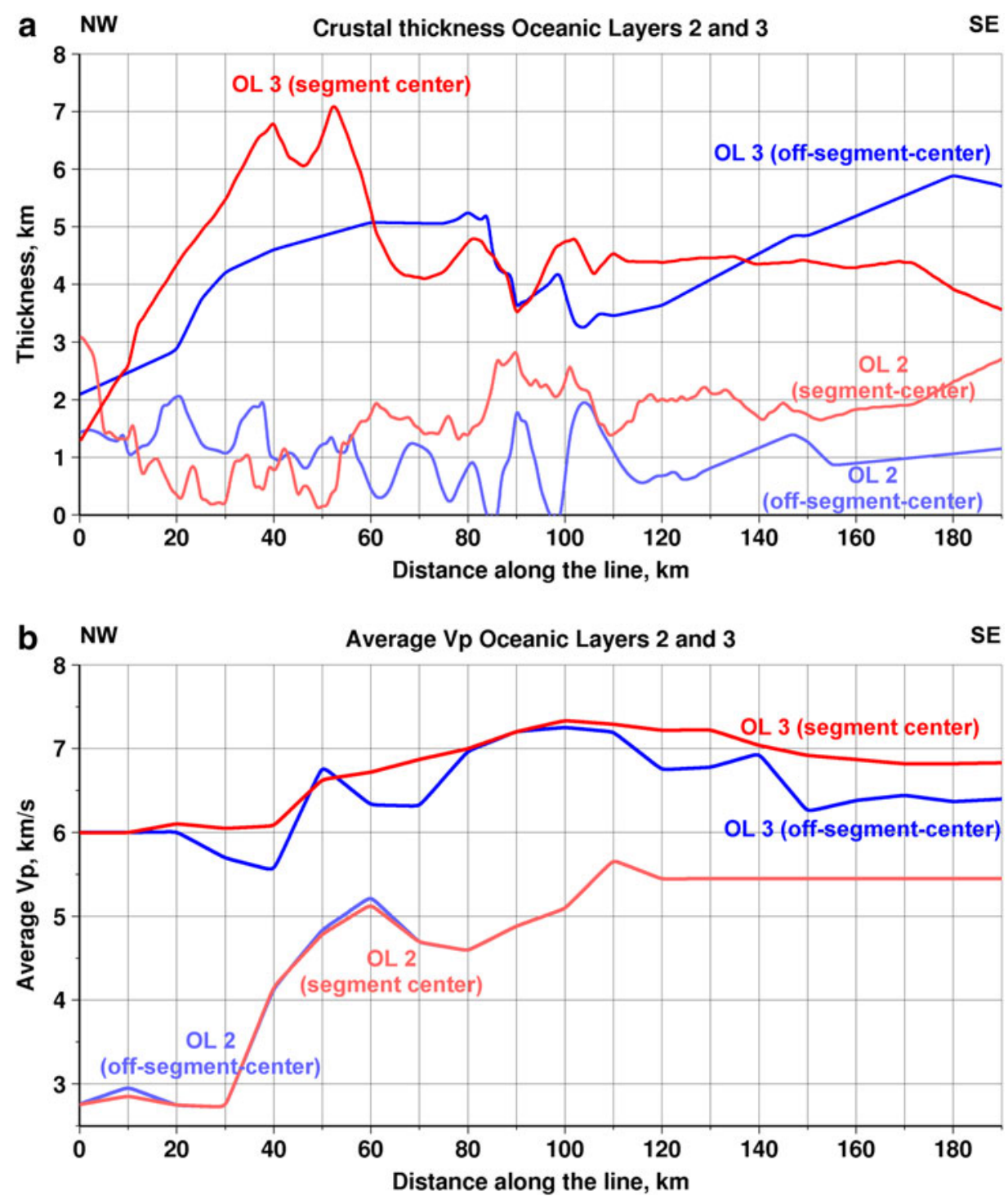

Fig. 12 a Variations along the line of the modeled thickness of Oceanic Layers 2 and 3 of the segment-center (present study, red lines) and the off-segment-center (Kandilarov et al. 2008, blue lines) segments; $\mathbf{b}$ variations along the line of the average modeled $\mathrm{P}$-wave

the model the density reaches its highest value (Fig. 10; Table 3).

The top of the mantle (Moho) is illuminated between 20 and $170 \mathrm{~km}$ (Fig. 9), dark parts of the model being complemented by the gravity model. In the section from $\sim 30$ and $110 \mathrm{~km}$ the seismic energy penetrates as deep as $4 \mathrm{~km}$ below the Moho and in the section from 120 to $170 \mathrm{~km}$ it penetrates more than $6 \mathrm{~km}$ below the Moho. Two discontinuous reflections in the mantle are observed between ca. 120 and ca. $170 \mathrm{~km}$ at depths $\sim 12-14 \mathrm{~km}$ and $\sim 16-18 \mathrm{~km}$, respectively. These so-called "floating reflections" are imaged by instruments 15 and 16 (Fig. 5). The seismic velocity in the mantle near the ridge is low seismic velocities for Oceanic Layers 2 and 3 of the segment-center (present study, red lines) and the off-segment-center (Kandilarov et al. 2008, blue lines) segments

$(6.7 \mathrm{~km} / \mathrm{s})$ and is known from a single velocity node. The velocity steadily increases from $6.7 \mathrm{~km} / \mathrm{s}$ in the beginning of the layer to $7.95 \mathrm{~km} / \mathrm{s}$ at approx. $60 \mathrm{~km}$ and from there to $190 \mathrm{~km}$ it has a constant value of $7.9 \mathrm{~km} / \mathrm{s}$. The modeled density of the mantle generally increases away from the rift axis (Fig. 10; Table 3).

An overview of the results from the off-segment center profile

To adequately compare SC and OSC models quantitatively and qualitatively we will briefly outline the main results and conclusions from the models along the OSC profile of 

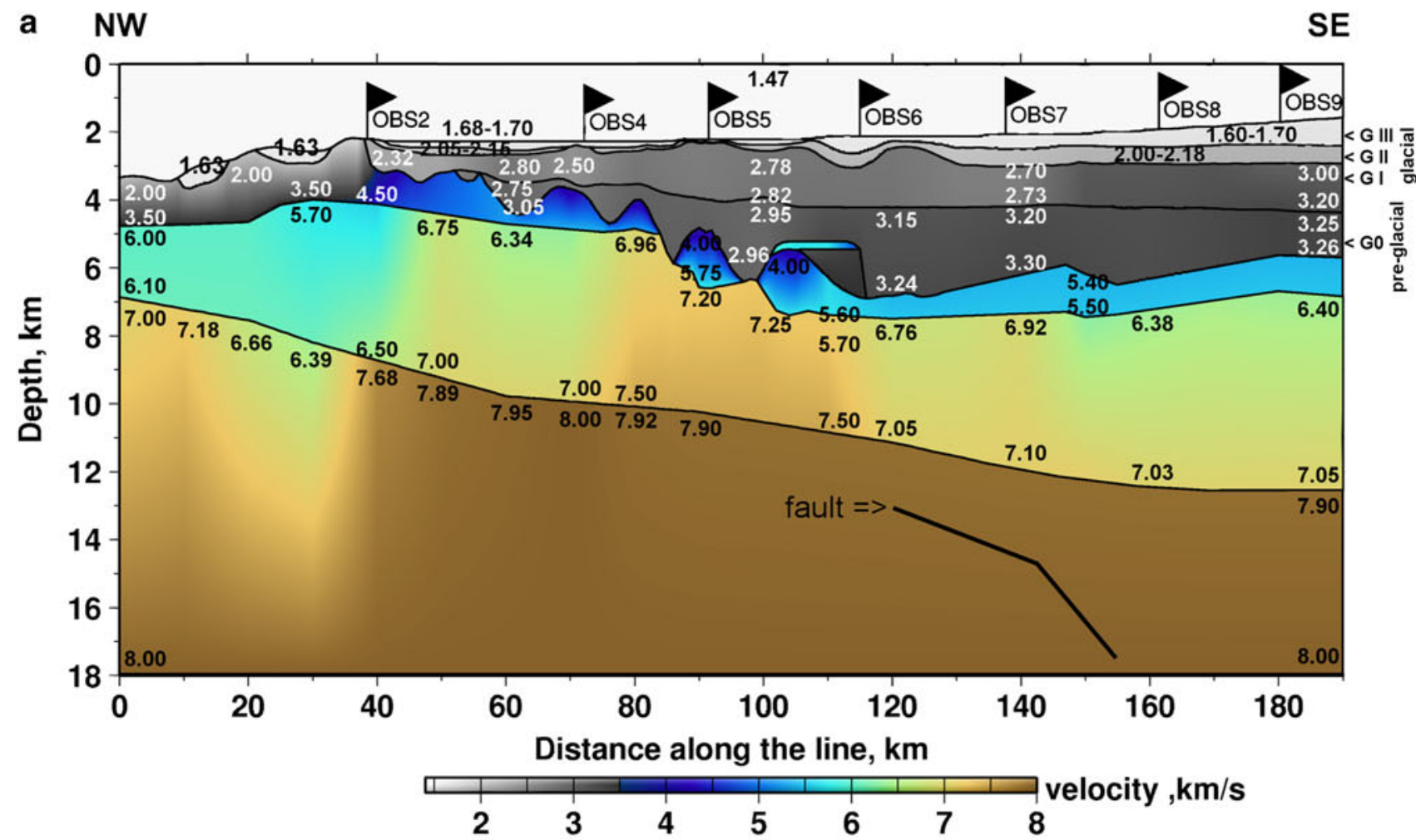
b $\quad$ sequence GIII - muddy sediments Eequence GII - muddy sediments undisturbed sequence $\mathrm{GI}$ - compacted muddy sediments or mudstone/shale disturbed sequence $\mathrm{GI}$ - compacted muddy sediments or mudstone/shale

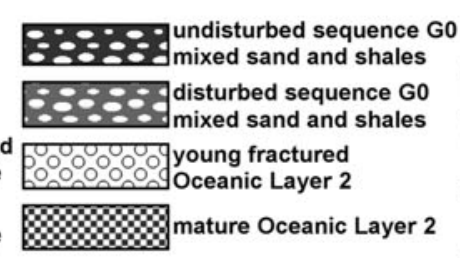

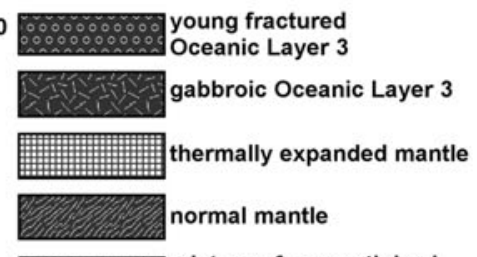

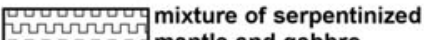
mantle and gabbro

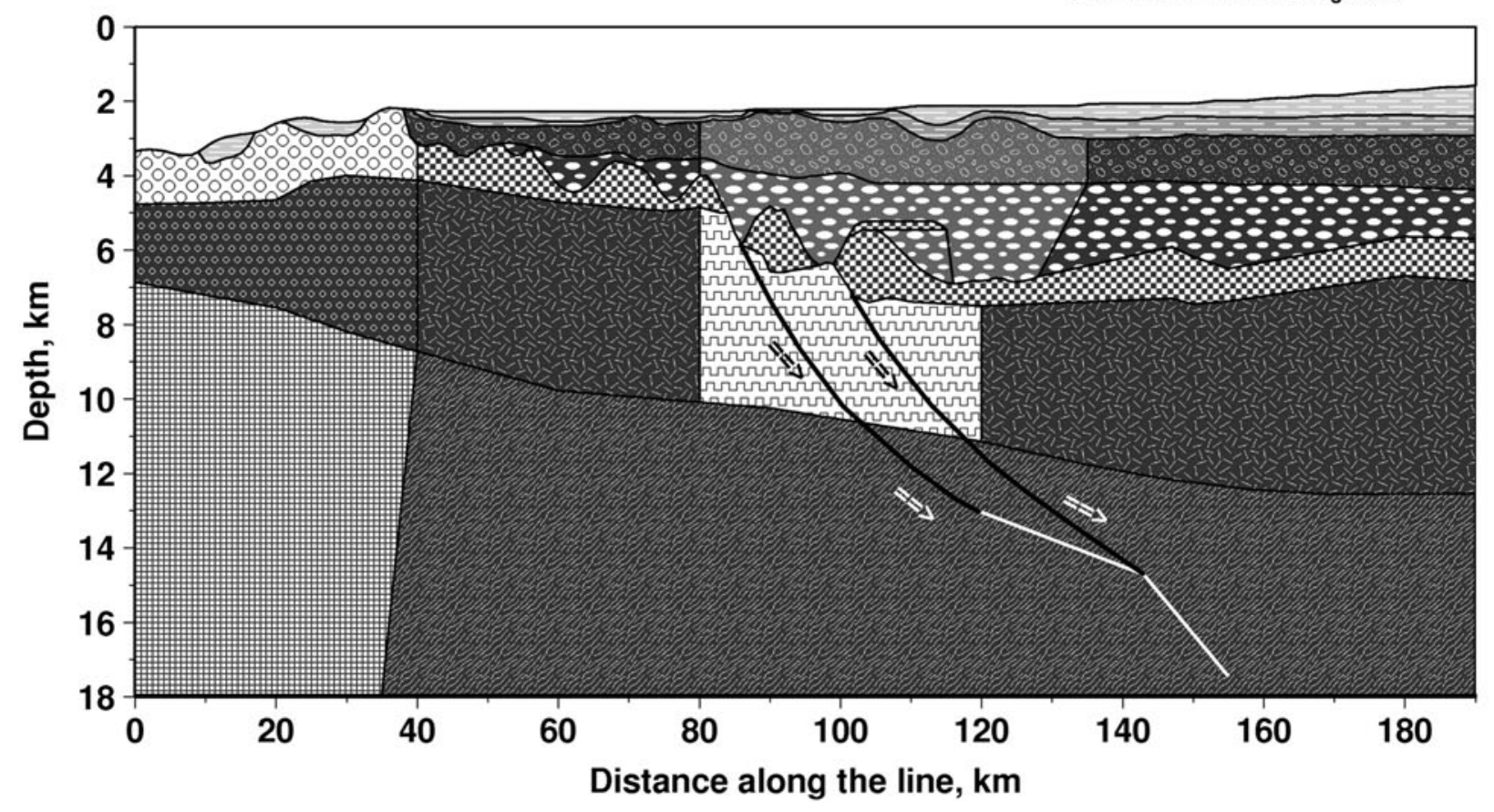


4 Fig. 13 a P-wave velocity model along the off-segment center presented by Kandilarov et al. (2008); numbers in black are the seismic velocities in $\mathrm{km} / \mathrm{s}$; b schematic geological interpretation of the model of Kandilarov et al. (2008)

Kandilarov et al. (2008) (Fig. 13). Results were obtained following the same procedures for both data processing and modeling.

The same regional reflections, GIII to G0, were observed in the MCS section of the OSC profile. Seismic velocities in the sedimentary layers are similar to the ones observed in the present model (Table 2; Fig. 13a). Modeled densities in the sedimentary layers of the OSC profile are also similar to those of the present model (Table 3). Layers GIII and GII in the OSC model represent unconsolidated muddy sediments, while layer GI consists of compacted muddy sediments or mudstone and layer G0 is composed of mixed sand and shale. The sedimentary formations in the middle part of the OSC profile are disturbed by several diapirs. These structures are associated with bottom simulating reflections (BSR) in the shallower sedimentary layers. No similar structures (sedimentary diapirs or BSRs) are observed in the MCS data of the SC profile and this constitutes the main difference between the two MCS sections.

The sub-basement area in the first $\sim 40 \mathrm{~km}$ of the model along the OSC profile has low P-wave velocities$2.0-3.5 \mathrm{~km} / \mathrm{s}$ in Oceanic Layer 2, 5.7-6.5 km/s in Oceanic Layer 3, and $6.4-7.2 \mathrm{~km} / \mathrm{s}$ in the mantle (Fig. 13a). The sub-basement zone in the first $\sim 40 \mathrm{~km}$ of the OSC profile were interpreted as young, thermally expanded, fractured, water saturated and fluid penetrated area, with its lower part being possibly serpentinized (Fig. 13b).

The mature Oceanic Layer 2 ( $>40 \mathrm{~km}$ along the line) is thin, discontinuous at some locations, and broken into several rotated fault blocks. The modeled seismic velocities are almost identical to the ones observed in the SC model (Figs. 12, 13a) but the thickness of Oceanic Layer 2 in the SC profile is always greater than zero. The fault blocks are possibly part of a major fault cutting deep into the mantle, where it is modeled as a floating reflection (Fig. 13). Two similar floating reflections were modeled in the present model.

The SC and OSC profiles differ most significantly in the mature parts ( $>40 \mathrm{~km}$ along the profile) of their Oceanic
Table 3 A table summarizing the results from the gravity modeling shown in Fig. 10b and the gravity model presented by Kandilarov et al. (2008). All density values are in units $10^{3} \mathrm{~kg} / \mathrm{m}^{3}$

\begin{tabular}{lllll}
\hline Layer & \multicolumn{2}{l}{ Position } & & \multicolumn{2}{l}{$\begin{array}{l}\text { Kandilarov et al. } \\
\text { (2008) }\end{array}$} \\
\cline { 2 - 4 } & \multicolumn{2}{l}{ Present study } & \\
\cline { 2 - 4 } & NW & Middle & SE & \\
\hline GIII & N/A & $1.67-1.70$ & 1.71 & $1.60-1.80$ \\
GII & N/A & $1.85-1.95$ & 2.00 & $1.90-2.20$ \\
GI & N/A & $2.06-2.17$ & 2.31 & $2.20-2.30$ \\
G0 & N/A & $2.13-2.22$ & 2.31 & 2.40 \\
OL2 & 2.20 & $2.55-2.57$ & $2.71-2.77$ & $2.30-2.80$ \\
OL3 & $2.78-2.83$ & $2.96-3.10$ & 3.25 & $2.75-3.15$ \\
Mantle & $3.16-3.29$ & 3.34 & $3.38-3.50$ & $3.25-3.47$ \\
\hline
\end{tabular}

Layer 3 in terms of both $V \mathrm{p}$ and density structure as well as the layer thickness. The difference is not so much in the values themselves but rather in the trend of those values along the line (Fig. 12). Oceanic Layer 3 is also an interesting feature in the OSC Vp model, its middle part being thin and characterized by high seismic velocities$7.2-7.5 \mathrm{~km} / \mathrm{s}$ and the adjacent parts being thicker and with seismic velocities typical for normal gabbroic Oceanic Layer 3: $6.4-7.0 \mathrm{~km} / \mathrm{s}$ (Fig. 13a). There seems to be a clear trend along the model of $\mathrm{Vp}$ and density vs layer thickness (thin crust-high $\mathrm{Vp}$ and thick crust-normal $\mathrm{Vp}$ (Fig. 12)), which correlates well with the tentative estimates of the spreading rate. This led to the conclusion that during periods of slower than present day spreading rate the generated crust was thinner and mixed with serpentinized mantle, while crust generated at present day spreading rate was thicker and with velocity structure and thickness closer to those for normal oceanic crust. The serpentinization processes that supposedly took place in the middle part of the model during slower spreading rates and the volumetric changes associated with them, may explain the presence of the diapirs disturbing the sedimentary layers and the BSRs in the shallow part of the profile. Serpentinization-related processes are also the likely explanation for a sill intrusion in the sediments, which has been detected through modeling (Fig. 13a).

The $\mathrm{Vp}$ and density structures along the top of the mantle of the OSC profile are similar to those in the present model. The $\mathrm{Vp}$ values oscillate around $8.0 \mathrm{~km} / \mathrm{s}$, while the
Table 2 A chart showing the sedimentary P-wave velocities obtained by this study and the studies of Kandilarov et al. (2008); Ljones et al. (2004) and Hjelstuen et al. (1996)

\begin{tabular}{lllll}
\hline Sequence & This study & Kandilarov et al. (2008) & Ljones et al. (2004) & Hjelstuen et al. (1996) \\
\hline GIII & $1.6-1.7$ & $1.60-1.70$ & $1.75-1.90$ & 1.9 \\
GII & $1.9-2.2$ & $2.00-2.18$ & $2.00-2.35$ & 2.2 \\
GI & $2.5-3.3$ & $2.30-3.20$ & $2.23-2.85$ & 2.6 \\
G0 & $2.7-3.3$ & $2.95-3.33$ & $2.90-4.15$ & 3.3 \\
\hline
\end{tabular}


density is increasing away from the start of the model. Based on these Kandilarov et al. (2008) proposed peridotitic composition for the mantle, while the density trend was attributed to thermal effects.

\section{Discussion}

\section{Sedimentary section}

The seismic velocities in sedimentary sequences GIII to G0 of our model are given in Table 2 along velocities of the same formations reported by Hjelstuen et al. (1996), Ljones et al. (2004) and Kandilarov et al. (2008). The velocities in GIII are lower than those reported by Hjelstuen et al. (1996) and Ljones et al. (2004). The seismic velocities in GII are correlative with the study of Hjelstuen et al. (1996) and, to some extent, with the values presented by Ljones et al. (2004). The low seismic velocities are attributed to high porosity and low degree of consolidation of the mineral grains that compose these layers. Based on the seismic velocities we propose that sedimentary sequences GIII and GII consist of water-saturated unconsolidated sediments. Given the knowledge we have about the depositional environment (Hjelstuen et al. 1996) we argue that the likely composition of GIII and GII are muddy sediments.

The velocities of GI provided by model are slightly higher than the values reported by Hjelstuen et al. (1996) and Ljones et al. (2004). We propose that the layer is composed of better compacted muddy sediments/mudstone (Domenico 1984; Kandilarov et al. 2008).

The velocities in G0 are lower than the values reported by Hjelstuen et al. (1996) and Ljones et al. (2004). The difference between the seismic velocities in GI and G0 in our model and the study of Hjelstuen et al. (1996) are mainly attributed to the distance between their survey area and ours. Based on the previous studies in the area and the results we obtained, we propose that the layer is composed of mixed sand and shale (Mjelde et al., 2003).

Igneous crust

\section{Oceanic Layer 2}

The modeled low velocities in the very young portion of the crust (first ca. $40 \mathrm{~km}$ ) are due to fractures, cracks and fluid circulation and possibly thermal expansion under the influence of the magmaticaly active zone, which is also observed in the MCS data (Figs. 2, 8; White et al. 1992; Grevmeyer and Weigel 1996). Closure of cracks, cessation of seawater circulation and cooling leading to thermal contraction, may account for the increase in seismic velocity observed from approx. $40 \mathrm{~km}$ of the model to ca. $110 \mathrm{~km}$ (Grevmeyer and Weigel 1996). The highly variable topography of the top of Oceanic Layer 2 in the area $\sim 50-110 \mathrm{~km}$ is interpreted as rotated fault blocks (Bruvoll et al. 2009). The increase in velocity from ca. $110 \mathrm{~km}$ to the end of the model is attributed to aging of the crust and compaction due to the weight of the sedimentary load (Bruvoll et al. 2009). The general density increase in Oceanic Layer 2 from the ridge towards the end of the model is attributed to closure of cracks, reduction in seawater circulation and thermal contraction (Ljones et al. 2004).

\section{Oceanic Layer 3 and the upper mantle}

The ray coverage along the entire Oceanic Layer 3 is denser and more evenly distributed than that along the overlaying Oceanic Layer 2 (Figs. 5, 6 and 12). We explain the relatively low seismic velocities in Oceanic Layer 3 in the immediate vicinity of the ridge by thermal expansion of the young crust, fractures and fissures, seawater circulation and possibly serpentinization (Klingelhofer et al. 2000; Klingelhofer and Geli 2000; Ritzmann et al. 2002; Ljones et al. 2004; Ritzmann et al. 2004; Kandilarov et al. 2008).

The absence of clear variations in P-wave velocity and thickness in the mature Oceanic Layer 3 lead us to conclude that $\mathrm{T}$ there are no clear relationships between spreading rate (estimated by Kandilarov et al. 2008) and thickness, P-wave velocity or density along this layer. The seismic velocities in Oceanic Layer 3 correspond to values typically found in gabbroic crust (White et al. 1992; Ljones et al. 2004). Therefore, we interpret Oceanic Layer 3 in our model to be composed of normal oceanic gabbroic crust. The somewhat higher seismic velocities along the two thickenings of Oceanic Layer 3 at ca. 85 and $100 \mathrm{~km}$ do not allow us to overrule the possibility of some small degree of serpentinization. However, in order for serpentinization to occur it is necessary for the crust to be thin and the mantle to be cool (Minshull et al. 1998), which is not the case here. The higher modeled density of Oceanic Layer 3 in the zone $\sim 140-190 \mathrm{~km}$ is attributed to the difficulty in decoupling the effects of the mantle and lower crust on the gravity field.

The low velocity $(6.7 \mathrm{~km} / \mathrm{s})$ in the mantle near the ridge is interpreted as thermally expanded, fluid penetrated and possibly serpentinized mantle. For the illuminated part of the mature mantle the almost constant seismic velocity points to normal mantle composition and lack of serpentinization. The southeastward increase of modeled density is considered an artificial modeling remnant caused by thermal effects in the mantle (Breivik et al. 1999). Similarity between dips of the floating 
Fig. 14 Schematic geological interpretation of the model. The location of the fault drawn on Fig. 2 is also shown
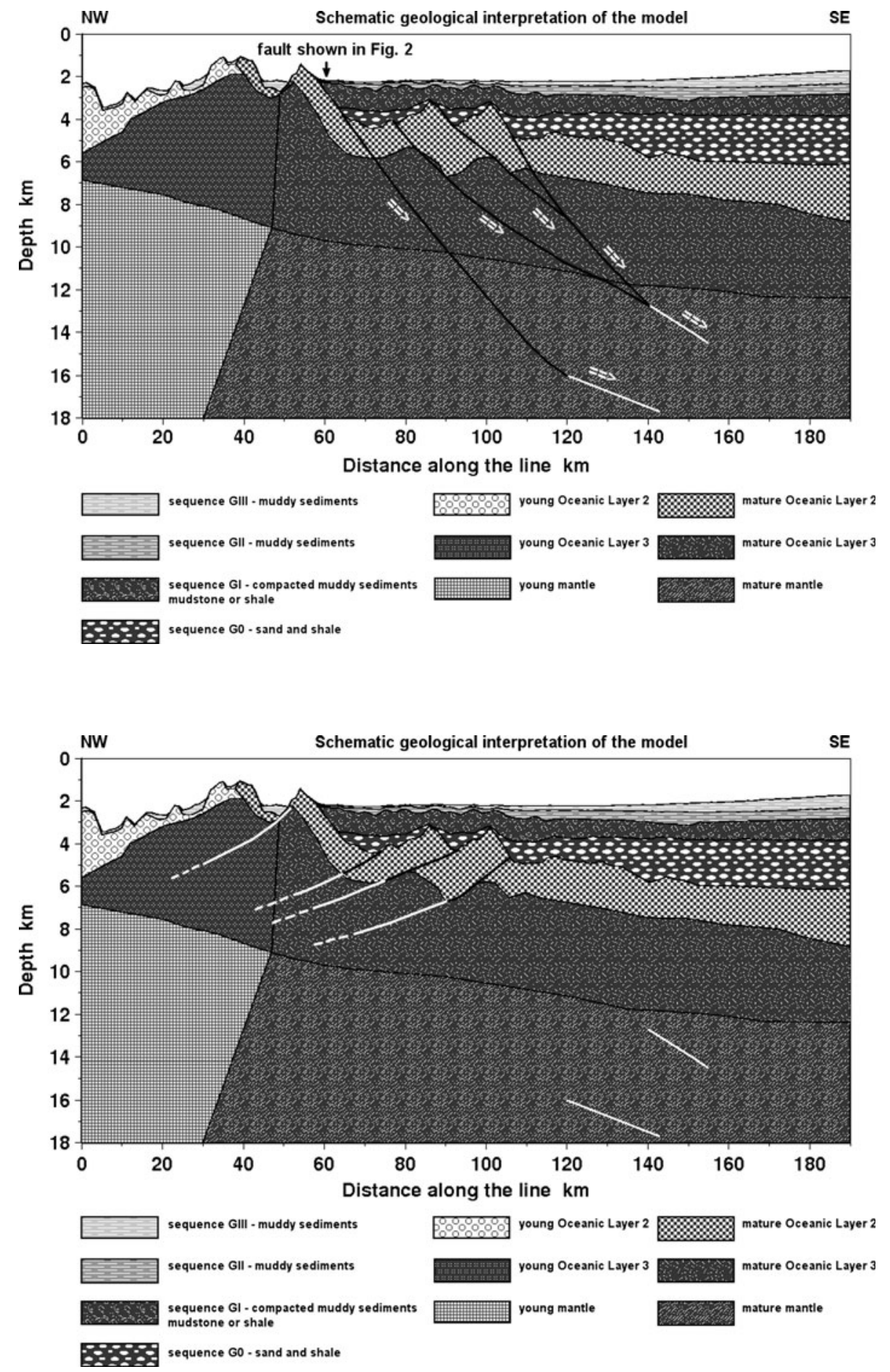

Fig. 15 Schematic alternative geological interpretation of the model if the floating reflections are neglected reflections observed in the mantle and the and in the southeastern flanks of the rotated fault blocks in Oceanic Layer 2 points to a possible connection between both features through a fault or a system of faults cutting deep down to the upper mantle. A schematic geological interpretation of our model is shown in (Fig. 14). This interpretation involves very low angle normal faults and block rotation towards the ridge axis. If the floating reflections are not connected to the shallower fault system, our preferred model would be a fault system with block rotation away from the spreading axis as typically seen at ridge flanks (Fig. 15). 
Comparison of the segment-center and off-segmentcenter profiles

After taking into account the modeling uncertainties, the segment-center (this study) and the off-segment-center (Kandilarov et al. 2008) profiles exhibit many similarities in the sedimentary succession and the young crust (first ca. $30-40 \mathrm{~km}$ ) attributed to identical physical properties of both layers, which is not surprising given the proximity of the two lines. In the mature part of the oceanic crust there are no significant variations in the modeled P-wave velocity (Fig. 12b) between the two profiles.

However, differences exist. The most prominent difference between the shallow sections of the two lines is the presence of sedimentary diapirs and bottom simulating reflections (BSR) in the MCS data of the OSC profile (Fig. 6 in Kandilarov et al. 2008), while no such features are observed in the MCS data of the present study (Fig. 6). Kandilarov et al. (2008) attribute the presence of these features in their MCS data to fluid migration caused by partial serpentinization of Oceanic Layer 3. We explain the lack of BSR and sedimentary diapirs in our MCS data with absence of serpentinization processes in Oceanic Layer 3 imaged on our (SC) profile.

The average crustal thickness in our model (SC) is $\sim 6.15 \mathrm{~km}$, while in the OSC model of Kandilarov et al. (2008) it is $\sim 5.4 \mathrm{~km}$. The thickness trends of both profiles are given in Figs. 14 and 15. Except for two narrow zones, the oceanic crust in the immediate vicinity of the ridge (the first ca. $30 \mathrm{~km}$ ) on the SC model is $\sim 0.3 \mathrm{~km}$ thicker than in the OSC model. At several locations in the section from $\sim 30$ to $150 \mathrm{~km}$ the crust of the SC model is as much as $2-2.8 \mathrm{~km}$ thicker than for the OSC model. Figure $12 \mathrm{a}$ shows that the larger thickness of the mature crust of the $\mathrm{SC}$ profile is confined to Oceanic Layer 2. The crust of the $\mathrm{SC}$ model is only thinner (max. $\sim 0.5 \mathrm{~km}$ at ca. $70 \mathrm{~km}$ ) than the OSC profile in a narrow section between 65 and $75 \mathrm{~km}$. From ca. 150 to $190 \mathrm{~km}$ the crust along the OSC profile is thicker than the $\mathrm{SC}$ profile with a maximum of ca. $0.75 \mathrm{~km}$. The generally greater crustal thickness in the SC model is attributed to increased magma production, which led to generation of crust having more normal thickness compared to the thinner crust generated under the OSC. This is consistent with observations made from the geochemistry of basalts recovered along this ridge. Hellevang and Pedersen (2005) concluded that magma production at this ridge occur both at and between the segment centers, despite the fact that the effective spreading rate is among the lowest known along the global ridge system. Basalts formed between segment centers can be distinguished from basalts formed at or close to the centers, and higher degrees of melting at the segment centers can explain the alongaxis variations.
Kandilarov et al. (2008) found dependence between the variation of the spreading rate along their profile and the thickness and seismic velocity trends of Oceanic Layer 3. In their model (OSC) slower spreading (5.5 mm/year) corresponds to thin, high-velocity, denser lower crust, interpreted to be composed of a mixture of serpentinized peridotite from the mantle and gabbro from Oceanic Layer 3. On the other hand, faster spreading $(8 \mathrm{~mm} /$ year $)$ corresponds to thicker, low-velocity, less dense lower crust interpreted to be normal gabbroic Oceanic Layer 3. After reinterpreting the direction of magnetic anomaly 6 from Kandilarov et al. (2008) (Fig. 3) we calculated slightly different past spreading rates along the different portions of our model but the trend of the spreading rate curve is the same as in their study. The reader should bear in mind though that the positions of the relocated magnetic anomaly 6 as well as magnetic anomalies 5 and 7, taken from Engen et al. (2008), are still very speculative. From these estimates and our modeling results we could not infer a clear dependence between spreading rate and crustal thickness/seismic velocity.

An open question in the study of Kandilarov et al. (2008) was whether the spreading rate controls the magmatic activity or vice versa. For spreading rates $>15 \mathrm{~mm} /$ year there is no dependency between crustal thickness and spreading rate, the generated crust being $7 \pm 1 \mathrm{~km}$ thick (White et al. 1992). For spreading rates $<15 \mathrm{~mm} / \mathrm{year}$ the generated crust is generally thinner and the thickness generally depends on the spreading rate-the slower the spreading is the thinner is the crust. The lack of clear correlation between spreading rate and crustal thickness/ seismic velocity in the SC model and the fact that the average crustal thickness and velocity that we infer from it correspond to normal oceanic crust, lead us to suggest that above a certain critical level of magmatism crust with normal thickness may be generated even at ultra-slow rates $(<12 \mathrm{~mm} /$ year $)$.

\section{Conclusions}

A marine survey for collecting OBS, MCS and gravity data was carried out in 2002 by the University of Bergen, Norway and Hokkaido University, Japan across the eastern side of the Knipovich Ridge, North Atlantic along a chain of seamounts that defines the segment center (SC) of a ridge. The survey resulted in the modeling of $\mathrm{P}$-wave velocity and gravity.

1. The models image pre-glacial sedimentary sequences GIII-to-GI and G0. Sequences GIII and GII consists of highly water saturated muddy sediments, having high porosity and low degree of consolidation. Sedimentary 
sequence GI is more compacted consolidated and less water saturated than the overlaying formations, as the muddy sediments are possibly replaced by mudstone. The pre-glacial sequence $\mathrm{G} 0$ corresponds to a mixture of sand and shale. The porosity of all sedimentary sequences decreases away from the ridge because of the increasing effect of compaction with depth.

2. The young portion of the oceanic crust is fractured, water penetrated and thermally expanded with possible serpentinization of Oceanic Layer 3. The crustal thickness reaches around $7 \mathrm{~km}$ in the first approx. $40 \mathrm{~km}$ from the ridge possibly due to the increased magmatic activity along the axial and off-axial highs.

3. The mature Oceanic Layer 3 is composed of normal gabbroic crust having almost uniform thickness.

4. The portion of the mantle near the ridge is thermally expanded, water penetrated and possibly serpentinized, while the mantle beneath the mature oceanic crust is normal and non-serpentinized.

5. Comparison with results from the OSC profile, reported by Kandilarov et al. (2008), reveals that while along the OSC profile there is a dependency between spreading rate and crustal thickness and seismic velocity, no such correlations are found for the SC profile. Along the OSC profile periods of slower spreading generated thin, high $\mathrm{Vp}$ crust while periods of faster spreading generated a crust having normal physical properties. Along the SC profile the crustal thickness and velocity are normal despite inner variations and ultra-slow spreading rate. This implies that increased magmatism may remove the dependency between spreading rate and crustal thickness that exists for slow and ultra-slow ridges.

6. The rotated fault blocks observed in Oceanic Layer 2 and the modeled floating reflections in the upper mantle that are inferred in both SC and OSC profiles point towards a fault normal located along the spreading direction and cutting down into the upper mantle.

Acknowledgments We would like to thank to the crew of RV Håkon Mosby and the engineers from the University of Bergen and Western Geco for their help during the survey. We are grateful to Fredrik Sætre for processing the navigation data. Professor Hideki Shimamura (Hokkaido University), Olvar Løvaas (Norwegian Petroleum Directorate) and Maarten Vanneste (University of Troms $\varnothing$ ) are acknowledged for their help and assistance in planning the survey. The authors also want to thank to Arne Gidskehaug from the University of Bergen for help in preparing the gravity data and to Professor Brian Robins for correcting the manuscript. We finally thank the Norwegian Petroleum Directorate, the Research Council of Norway, University of Bergen and Hokkaido University for the financial and technical support.
Open Access This article is distributed under the terms of the Creative Commons Attribution Noncommercial License which permits any noncommercial use, distribution, and reproduction in any medium, provided the original author(s) and source are credited.

\section{References}

Austegard A, Sundvor E (1991) The Svalbard continental margin: crustal structure from analysis of deep seismic profiles and gravity, In Institute of Solid Earth Physics University of Bergen Seismo Series 53: 1-33

Batiza R (1996) Magmatic segmentation of mid oceanic ridges: a review. In: MacLeod CJ, Tyler PA, Walker CL (eds) Tectonic, magmatic, hydrothermal and bilogical segmentation of midoceanic ridges Geological society special publication No 118, pp 103-130. doi:10.1144/GSL.SP.1996.118.01.06

Bown JW, White RS (1994) Variation with spreading rate of oceanic crustal thickness and geochemistry. Earth Planet Sci Lett 121:435-449

Breivik AJ, Verhoef J, Ide JI (1999) Effect of thermal contrasts on gravity modeling at passive margins: results from the western Barents Sea. J Geophys Res 104(B7):15239-15311

Breivik AJ, Mjelde R, Grogan P, Shimamura H, Murai Y, Nishimura Y, Kuwano A (2002) A possible Caledonite arm through the barents Sea imaged by OBS data. Tectonophysics 355:67-97

Breivik A, Mjelde R, Grogan P, Shimamura H, Murai Y, Nishimura Y (2003) Crustal structure and transform margin development south of Svalbard based on ocean bottom seismometer data. Tectonophysics 369:37-70

Breivik A, Mjelde R, Grogan P, Shimamura H, Murai Y, Nishimura Y (2005) Caledonite development offshore-onshore Svalbard based on ocean bottom seismometer, conventional seismic, and potential field data. Tectonophysics 401:79-117

Brozena JM, Childers VM, Lawver LA, Gahagan LM, Forsberg R, Faleide JI, Eldholm O (2003) New aerogeophysical study of the Eurasia Basin and Lomonosov Ridge: implications for basin development. Geology 31(9):825-828

Bruvoll V, Breivik AJ, Mjelde R, Pedersen RB (2009). Burial of the Mohn-Knipovich seafloor spreading ridge by the Bear Island Fan: time constraints on tectonic evolution from seismic stratigraphy. Tectonics, 28, TC4001. doi:10.1029/2008TC002396

Cannat M, Mevel C, Maia M, Deplus C, Durand C, Gente P, Agrinier P, Belarouchi A, Dubuisson G, Humler E, Reynolds J (1995) Thin crust, ultramafic exposures, and rugged faulting patterns at the Mid-Atlantic ridge (22O-24ON). Geology 23(1):49-52

Crane K, Sundvor E, Foucher J-P, Hobart M, Myhre AM, LeDouaran S (1988) Thermal evolution of the Western Svalbard Margin. Mar Geophys Res 9:165-194

Crane K, Sundvor E, Buck R, Martinez F (1991) Rifting in the northern Norwegian-Greenland Sea: thermal tests of asymmetric spreading. J Geophys Res 96:14529-14550

Crane K, Doss H, Vogt P, Sundvor E, Cherkashov G, Poroshina I, Joseph D (2001a) The role of the Spitsbergen shear zone in determining morphology, segmentation and evolution of the Knipovich Ridge. Mar Geophys Res 22:153-205

Crane K, Doss H, Vogt P, Sundvor E (2001b) Morphology of the Northeastern Mohns Ridge: results from SeaMARC II Surveys in the Norwegian-Greenland Sea. Explor Mining Geol 8:323-339

Dick HJB, Lin J, Schouten H (2003) An ultra slow spreading class of ocean ridge. Nature 426:405-412 
Domenico SN (1984) Rock lithology and porosity determination from shear and compressional wave velocity. Geophysics 49(8):11881195

Eiken O, Austegard A (1987) The Tertiary orogenic belt of WestSpitsbergen: seismic expressions of the offshore sedimentary basins. Norsk Geologisk Tidskrift 67:383-394

Eldholm O, Faleide JI, Myhre A (1987) Continent-ocean transition at the western Barents Sea/Svalbard continental margin. Geology 15:1118-1122

Engen O, Eldholm O, Bungum H (2003) The Arctic plate boundary. J Geophys Res 108(B2):2075. doi:1029/2002JB001809

Engen O, Faleide JI, Dyreng TK (2008) Opening of the Fram Strait gateway: a review of plate tectonic constraints. Tectonophysics 450:51-69

Faleide JI, Solheim A, Fiedler A, Hjelstuen BO, Andersen E, Vanneste K (1996) Late Cenozoic evolution of the western Barents Sea-Svalbard continental margins. Global Planet Change 12:53-74

Fiedler A, Faleide JI (1996) Cenozoic sedimentation along the southwestern Barents Sea margin in relation to uplift and erosion of the shelf. Global Planet Change 12:75-93

Glebovsky V, Likhachev A, Kristoffersen Y, Engen Ø, Faleide JI, Brekke H (2006) Sedimentary thickness estimations from magnetic data in the Nansen Basin. In: Scott RA, Thurston DK (eds) Proceedings of the fourth international conference on arctic margins.OCS StudyMMS2006-003. US Department of the Interior, Anchorage, AK, pp 157-164

Grevmeyer I, Weigel W (1996) Seismic velocities of the uppermost igneous crust versus age. Geophys J Int 124:631-635

Hellevang B, Pedersen R-B (2005) Magmatic segmentation of the northern Knipovich Ridge: evidence for high-pressure fractionation at an ultraslow spreading ridge. Geochem Geophys Geosyst 6:Q09007. doi:10.1029/2004GC00898

Hjelstuen BO, Elverhøi A, Faleide JI (1996) Cenozoic erosion and sediment yield in the drainage area of the Storfjorden Fan. Global Planet Change 12:95-117

Holbrook WS, Reiter EC, Purdy GM, Sawyer D, Stoffa PL, Austin JA Jr, Oh J, Makris J (1994) Deep structure of the U.S. Atlantic continental margin, offshore South Carolina, from coincident ocean bottom and multichannel seismic data. J Geophys Res 99(B5):9155-9178

Jokat W, Ritzmann O, Schmidt-Aursch MC, Drachev S, Gauger S, Snow J (2003) Geophysical evidence for reduced melt production on the Arctic ultraslow Gakkel mid-ocean ridge. Nature 423:962-965

Kandilarov A, Mjelde R, Okino K, Murai Y (2008) Crustal structure of the ultra-slow spreading Knipovich Ridge, North Atlantic, along a presumed amagmatic portion of oceanic crustal formation. Mar Geophys Res 29(2):109-134. doi:10.1007/s11001008-9050-0

Klingelhofer F, Geli L (2000) Geophysical and geochemical constraints on crustal accretion on the very-slow spreading Mohns ridge. Geophys Res Lett 27(10):1547-1550

Klingelhofer F, Geli L, Matias L, Steinsland N, Mohr J (2000) Crustal structure of a super-slow spreading centre: a seismic refraction study of Mohns Ridge, 72N. Geophys J Int 141: $509-526$

Ljones F, Kuwano A, Mjelde R, Breivik A, Shimamura H, Murai Y, Nishimura Y (2004) Crustal transect from the North Atlantic Knipovich Ridge to the Svalbard Margin west of Hornsund. Tectonophysics 378:17-41

Ludwig WI, Nafe JE, Drake CL (1970) Seismic refraction. In: Maxwell AE (ed) The sea, vol 4. Wiley, New York, pp 53-84

Lundin E, Doré AG (2002) Mid-Cenozoic post break-up deformation in the "passive" margins bordering the Norwegian-Greenland Sea. Marine Petroleum Geol 19:79-93
Minshull TA, Muller MR, Robinson CJ, White RS, Bickle MJ (1998) Is the oceanic Moho a serpentinization front? In: Mills RA, Harrison K (eds) Modern ocean floor processes and the geological record. Geological Society of London, Special Publication 148, pp 71-80

Mjelde R, Digranes P, Shimamura H, Shiobara H, Kodaira S, Brekke H, Egebjerg T, Sørenes N, Thorbjornsen S (1998) Crustal structure of the northern part of the Vøring Basin, mid-Norway margin, from wide angle seismic and gravity data. Tectonophysics 293:175-205

Mjelde R, Raum T, Digranes P, Shimamura H, Shiobara H, Kodaira S (2003) Vp/Vs ratio along the Vøring Margin, NE Atlantic, derived from OBS data: implications on lithology and stress field. Tectonophysics 369:175-197

Mjelde R, Raum T, Myhren B, Shimamura H, Murai Y, Takanami T, Karpuz R, Næss U (2005) Continent-ocean transition on the Vøring Plateau, NE Atlantic, derived from densely sampled ocean bottom seismometer data. J Geophys Res 110:B05101. doi:10.1029/2004JB003026

Mjelde R, Raum T, Kandilarov A, Murai Y, Takanami T (2008) Crustal structure and evolution of the outer Møre Margin, NE Atlantic (in press)

Mosar J, Torsvik T H, The BAT team (2002b) Opening of the Norwegian and Greenland Seas: plate tectonics in Mid Norway since the Late Permian. In: Eide EA (coord) BATLAS-Mid Norway plate reconstructions atlas with global and Atlantic perspective, Geological Survey of Norway, pp 48-59

Mosar J, Eide EA, Osmundsen PT, Sommaruga A, Torsvik TH (2002) Greenland-Norway separation: a geodynamic model for the North Atlantic. Nor J Geol 82:281-298

Myhre A (1984) Compilation of seismic velocity measurements along the margins of the Norwegian Greenland Sea. Norsk Polarinstitut Skrift 180:41-61

Myhre A, Eldholm O, Sundvor E (1982) The margin between Senja and Spitsbergen fracture zones: implications from plate tectonics. Tectonophysics 89:33-50

Okino K, Curewitz D, Asada M, Tamaki K, Vogt P, Crane K (2002) Preliminary analysis of the Knipovich Ridge segmentation: influence of focused magmatism and ridge obliquity on an ultraslow spreading system. Earth Planet Sci Lett 2002:275-288

Pedley RC (1993) GRAVMAG-User Manual. Interactive 2.5D Gravity and Magnetic Modeling Program, British Geological Survey, Keyworth, Nottingham

Raum T, Mjelde R, Digranes P, Shimamura H, Shiobara H, Kodaira S, Haatvedt G, Sørenes N, Thorbjørnsen T (2002) Crustal structure of the southern part of the Vøring Basin, mid-Norway margin, from wide angle seismic and gravity data. Tectonophysics 355:99-126

Ritzmann O, Jokat W, Mjelde R, Shimamura H (2002) Crustal structure between the Knipovich Ridge and the Van Mijenfjorden (Svalbard). Mar Geophys Res 23:379-401

Ritzmann O, Jokat W, Czuba W, Guterch A, Mjelde R, Nishimura Y (2004) A deep seismic transect from Hovgård Ridge to northwestern Svalbard across the continent-ocean transition: a sheared margin study. Geophys J Int 157:683-702. doi:10.1111/ j.1365-246X.2004.02204.x

Sundvor E, Eldholm O (1979) The western and northern margin off Svalbard. Tectonophysics 58:239-250

Talwani M, Eldholm O (1977) Evolution of the Norwegian-Greenland Sea. Geol Soc Am Bull 88:969-999

Torsvik TH, Van der Voo R, Meert J, Mosar J, Walderhaug HJ (2001) Reconstructions of the continents around the North Atlantic at about the $60^{\text {th }}$ parallel. Earth Planet Sci Lett 187:55-69

White RS, McKenzie D, O’Nions K (1992) Oceanic crustal thickness from seismic measurements and rare elements inversions. J Geophys Res 97(B13):19683-19715 
Zelt CA (1999) Modelling strategies and model assessment for wide angle seismic traveltime data. Geophys J Int 139:183-204

Zelt CA, Ellis RM (1988) Practical and efficient ray tracing in twodimensional media for rapid traveltime and amplitude forward modeling. Can J Explor Geophys 24:16-31
Zelt CA, Smith RB (1992) Seismic traveltime inversion for 2-D crustal velocity structure. Geophys J Int 108:16-34 